\title{
Emergency remote education in foreign and second language teaching
}

\author{
Yunus Emre Akbana \\ Kahramanmaraş Sütçü İmam University, Faculty of Education, English Language Teaching, Kahramanmaraş, \\ Turkey, yemreakbana@gmail.com \\ Stefan Rathert \\ Kahramanmaraş Sütçü İmam University, Faculty of Education, English Language Teaching, Kahramanmaraş, \\ Turkey, strathert@gmail.com \\ Reyhan Ağçam \\ Kahramanmaraş Sütçü İmam University, Faculty of Education, English Language Teaching, Kahramanmaraş, \\ Turkey, reyhanagcam@gmail.com
}

\begin{abstract}
This study aims at tracing the effects of emergency remote education due to Covid-19 on foreign/second language teaching documented in research papers and reports. Employing document analysis, it identifies the research contexts and key findings reported in the studies published between 1 January and 28 October 2020. The findings indicate that a significant number of publications consist of reports presented by practitioners, i.e. schools, governmental authorities and educational foundations, and that the tertiary level is the most frequently covered context in the papers. The analysed publications report slightly more Emergency Remote Teaching (ERT)-driven affordances for teachers than constraints and suggest that both teachers and students are able to turn challenges of ERT into affordances when they receive sufficient support from governmental authorities, schools or peers and benefit from already acquired digital skills and technical infrastructure available. The findings also indicate a gap of research based on classroom data, which would more effectively contribute to an understanding of the challenges and affordances of ERT in language teaching.
\end{abstract}

Keywords: Covid-19, Emergency remote teaching, Foreign and second language education, Language teaching, Online learning

\section{Yabancı dil ve ikinci dil öğretiminde zorunlu uzaktan eğitim}

ÖZ Bu çalışmada, Covid-19 salgını nedeniyle uygulanan zorunlu uzaktan eğitimin yabancı/ikinci dil öğretimi üzerindeki etkilerini konu alan araştırmaların incelenmesi amaçlanmıştır. Doküman analizi yöntemi ile 1 Ocak ve 28 Ekim 2020 tarihleri arasında yayımlanan çalışmalarda belirtilen araştırma bağlamları ile öne çıkan bulgular tanımlanmıştır. Araştırmanın bulguları, analiz edilen yayınların önemli bir bölümünün uygulayıcılar, yani okullar, hükümet yetkilileri ve eğitim kurumları tarafından sunulan raporlardan oluştuğunu ve yükseköğretim düzeyinin makalelerde en sık ele alınan eğitim bağlamı olduğunu ortaya çıkarmıştır. İncelenen yayınlar, zorunlu uzaktan eğitimin yabancı/ikinci dil öğretmenlerine yönelik kısıtlamadan çok olanak sağladığı ve hem öğretmenlerin hem de öğrencilerin devlet yetkililerinden, okullardan veya akranlarından yeterli destek almaları ve hâlihazırda edinilmiş dijital becerileri ile mevcut teknik altyapıdan yararlanmaları halinde bu süreçte karşılaşılan zorlukları firsata çevirebileceği anlaşılmaktadır. Bulgular ayrıca, zorunlu uzaktan eğitimin ikinci/yabancı dil öğretiminde beraberinde getirdiği güçlükler ve firsatların daha etkili bir şekilde anlaşılmasına olanak sağlamak üzere sınıflardan gelecek verilere dayalı araştırma boşluğunun bulunduğuna işaret etmektedir.

Anahtar

Citation: $\quad$ Akbana, Y. E., Rathert, S., \& Ağçam, R., (2021). Emergency remote education in foreign and second language teaching. Turkish Journal of Education, 10(2), 97-124. https://doi.org/10.19128/turje.865344 


\section{INTRODUCTION}

Integrating information technologies and online tools into educational settings has been on the agenda since the post-World Word II era when the term 'educational technology' was initially used in the USA to refer to "technologies such as film strips, slide projectors, language laboratories, audio tapes, and television" (Coley et al., 1997, p. 9). Within the course of time, these technologies have become a part of educational practices at institutions of various levels for the ultimate aim of improving learning regardless of the modality of education. Nonetheless, there is ample evidence that integrating technologies into education exerts certain constraints along with opportunities from the perspectives of both practitioners and learners (Atkins et al., 2007; Collins \& Halverson, 2018; Hew \& Brush, 2007; Piccoli et al., 2001; Ruggiero \& Mong, 2015; Sun et al., 2008). From this viewpoint, investigating the impact of using information technology on young learners' achievement, Watson (1993) reported its positive effects such as increased concentration and motivation, and identified the following negative factors involved in the process: (i) teachers having insufficient knowledge of the software and understanding of the principles behind its use, (ii) students being unable to cooperate effectively, (iii) students having difficulties in learning to use the software, and (iv) the existence of a minimum threshold to make the use of Information Technology effective. In a similar fashion, Beldarrain (2006) argues that "although emerging technologies offer a vast range of opportunities for promoting collaboration in both synchronous and asynchronous learning environments, distance education programs around the globe face challenges that may limit or deter implementation of these technologies" (p. 139). In a qualitative research on the use of affordances and constraints to evaluate the use of information and communications technology (ICT) in teaching and learning, Kennewell (2001) points to a variety of factors which may influence the success of a teaching episode: "Variables concerning the teacher, students, classroom organisation, resources, subject/classroom culture and norms (rules, routines and expectations) will influence what and how students learn. ICT will not act independently of these" (p. 102).

\section{Emergency Remote Teaching}

Affordances and constraints of ICT have recently gained greater significance due to the Covid-19 pandemic which forced schools, colleges, universities and other educational institutions worldwide to stop face-to-face instructional practices and to continue their education in the form of remote teaching. This necessitated an increased integration of information technologies into educational environments regardless of the digital literacy of the primary stakeholders taking part in the process of instruction delivery. Since remote teaching using online tools has apparently been the only option available to address the challenge of the pandemic, the term emergency remote teaching (ERT) has become established to distinguish this form of remote teaching from other forms of distant teaching and learning (Hodges et al., 2020). In a comprehensive research on the interruption of education due to the Covid-19 pandemic, Bozkurt et al. (2020) attempted to report on overall views, reflections from various educational levels, lessons learned and suggestions in 31 countries. In line with Hodges et al. (2020), Bozkurt et al. (2020) distinguished between ERT and other forms of virtual education underlining that "the current practices can be defined as emergency remote education and this practice is different from planned practices such as distance education, online learning or other derivations" ( $\mathrm{p}$. 1). The research in concern produced significant findings regarding ERT practices around the world ranging from the effects of social injustice, inequity and divergent access to digital resources and skills on instructional practices and emerging educational roles of parents to psychological effects exerted by ERT on various stakeholders. In the light of these findings, the researchers advocate a pedagogy of care, affection and empathy along with the use of "alternative assessment and evaluation methods as well as concerns about surveillance, ethics, and data privacy resulting from nearly exclusive dependency on online solutions" (Bozkurt et al., 2020, p. 1). 
It can be assumed that potential impacts of the transition from teaching in physical environments to ERT are particularly massive in foreign or second language teaching because language is not only the medium through which academic content is taught and learned but it is also the academic subject itself (Long, 1983). Classroom language is eminently important for the creation of learning opportunities (Walsh, 2006), and anecdotal evidence suggests that classroom discourse in virtual classrooms differs strikingly from that in physical classrooms: Given the significance of interaction in language learning and teaching, ERT reduces the opportunities to make input more comprehensible because verbal and non-verbal cues or objects (realia) are not or to less extent implementable in instructional practices compared to physical classrooms (Sayer \& Braun, 2020). Apart from these aspects, there are a variety of factors to be considered for an evaluation of ERT including teachers', learners', parents' and school managers' familiarity with technical tools, equipment and internet access available or attitudes towards online teaching. To compensate for potentially negative impacts of the delivery of foreign or second language teaching, schools and teachers are requested to deal with the perceived constraints, to benefit from affordances emerging and to report on implementations to address the specific challenges of ERT. Reporting best practices may contribute to the development of an online teaching pedagogy for language teaching and learning that is conducive to engaging language learners and informing contexts that deliberately benefit from distant learning, possibly in hybrid forms combining physical and online teaching (Marshall \& Kostka, 2020).

Due to the novelty of the pandemic, publication of research on ERT in foreign and second language teaching has just started to emerge. A preliminary review of the existing literature indicates that an increasing number of studies have been carried out primarily on ERT practices in foreign/second language education and challenges encountered during the process by using various data collection tools ranging from questionnaires to interviews with different stakeholders including teachers, administrators and students. Besides, it is seen that especially higher education institutions have released reports mostly comprised of recommendations for the solutions of (possible) challenges of ERT practices and virtual learning environments to enable both students and practitioners to maximise the benefits of these practices. Yet, it appears to be necessary to describe and outline to what extent and from which perspectives ERT practices of foreign/second language education have been investigated since the outbreak of the pandemic and what kind of findings related to this concern have been reported in the published works to date. In that regard, this paper intends to give an overview of what has been studied so far, to report insights and to indicate gaps that should be further focused on. Hence, it is hoped to contribute to the existing literature on ERT in foreign/second language education around the world via its results and especially by identifying the research gap(s) to bridge by the scholars working in the field. The study also might present generic implications for the considerations of curriculum designers, policy makers and teacher educators to develop insights into this new modality of teaching and generate solutions to faced challenges.

\section{Research Questions}

Against the backdrop of the increased significance of ERT, this study attempts to view the growing body of literature on foreign/second language teaching in the times of Covid-19 by addressing the following research questions:

1) What are the characteristics (publication types, research methods, locations, educational contexts, participants) of literature on ERT in foreign language instruction?

2) What affordances and constraints of the ERT are reported in the literature?

\section{METHODOLOGY}

The research aim along with the thematic scope and the restricted time span out of which scholarly papers were analysed led to the decision to employ a qualitative document analysis informed by the 
scoping review approach. This appeared to be preferable because we assumed that the body of literature would present "emerging evidence" (Munn et al., 2018, p. 2) due to the novelty of ERT as a response to the Covid-19 pandemic. In the following sections, the research design is introduced and the steps in the document analysis are explained.

\section{Research Design}

Selecting a qualitative research design, the current study employed a document analysis (Bowen, 2009). The document analysis was informed by the scoping review approach that allows rapidly and comprehensively mapping the research area under consideration; this approach aims at identifying the available literature, indicating research priorities and gaps as well as summarising evidence presented in the literature (Levac et al., 2010). The document analysis was particularly guided by the observation that the scholarly examination of effects of ERT on foreign or second language teaching was ongoing and, therefore, a preliminary assessment without the intention to critically appraise the research available was preferable (Grant \& Booth, 2009). Additionally, decisions concerning the research design were guided by the need to include not only research articles that have undergone reviewing processes to ensure scientific reliability and validity but also other sources of relevance such as reports coming from stakeholders in schools exposed to ERT (cf. Davies et al., 2020).

The current study considered research strategies in comparable educational research (e.g. Fray \& Gore, 2018; Hung et al., 2018; Major \& Watson, 2018; O’Flaherty \& Phillips, 2015) and used a protocol to base the procedures followed on validated frameworks (e.g. Levac et al., 2010). The procedures comprised of (a) the formulation of research questions covering the purpose of the document analysis, (b) the identification of relevant studies based on exclusion and inclusion criteria, (c) data extraction from the selected studies, (d) charting the data employing numerical summary and coding based on thematic analysis and (e) summarising and reporting the results so that implications for further research and policy design can be drawn or practical implementations can be suggested (Bowen, 2009; Tricco et al., 2016). A detailed account of the procedures followed is given in the following sections.

\section{Identification of the Relevant Literature}

After formulating the research questions based on the research interest (see the Introduction), it was decided to use the databases ISI Web of Knowledge (i.e. Web of Science [WoS]) and Education Resources Information Center (ERIC) to identify relevant papers. As the research topic was connected to the Covid-19 pandemic, studies between 1 January 2020 and 28 October 2020 (inclusive) were considered assuming that no studies were available prior to this time span. The rationale behind selecting these two databases was to include high-quality papers given the standards required for being indexed in WoS and ERIC. A further reason was the consideration of ERIC as a database covering educational research that may provide us with reports not published in academic journals. After initial searches using Boolean operators including the terms 'foreign language', 'foreign language teaching', 'foreign language learning', and the same combinations replacing the initial word 'foreign' with 'second' and 'coronavirus', 'pandemic', we conducted the search by selecting '(language AND Covid19)' to serve feasibility and comprehensibility. In WoS, we excluded studies that were not included in the three categories - Educational Research, Language Linguistics, and Linguistics - by using the filters provided by the database.

The search in WoS revealed 57 papers, and in ERIC 40 papers matched the search criteria. After identifying 16 papers that were in both databases, the next step included the exclusion of papers that were not related to our research interest based on manual examination. Only those which were directly related to foreign or second language teaching in formal instruction and which had an explicitly formulated connection to the pandemic were included. The exclusion procedure was conducted by two researchers analysing the same set of papers. This procedure, which was basically followed also in analysing the papers accepted for inclusion, is shown in Table 1. 
Table 1.

Distribution of Exclusion and Analysis

\begin{tabular}{llll}
\hline & 1 st author and 2nd author & 1 st author and 3rd author & 2nd author and 3rd author \\
\hline $\begin{array}{l}\text { Exclusion } \\
\text { procedures }\end{array}$ & $\begin{array}{l}1 / 3 \text { of the papers received } \\
\text { from WoS and ERIC }\end{array}$ & $\begin{array}{l}1 / 3 \text { of the papers received } \\
\text { from WoS and ERIC }\end{array}$ & $\begin{array}{l}1 / 3 \text { of the papers received } \\
\text { from WoS and ERIC }\end{array}$ \\
$\begin{array}{l}\text { Analysis } \\
\text { procedures }\end{array}$ & \multicolumn{2}{c}{ initial analysis of 10 papers included in analysis (separately by each researcher) } \\
\cline { 2 - 4 }
\end{tabular}

The researchers held regular meetings throughout the study to compare their exclusion results. In case of dissent, the third researcher who was not involved in the decision of inclusion/exclusion of a specific paper was consulted. At the end of the exclusion procedures, 45 publications were included in the analysis. The list of included publications is given in Appendix 1.

\section{Data Analysis}

Based on the research questions, the following sets of information were extracted from the articles included: type of published paper, research method, countries, educational contexts, number of participants, and affordances and constraints reported. While the first five parameters were unambiguous, even though results concerning them were confirmed by at least two researchers throughout the study, the identification of affordances and constraints required qualitative coding procedures. To this end, the first ten articles retrieved from WoS were analysed by all three researchers separately. Applying a structural coding strategy, i.e. taking the second research question as guidance (Saldaña, 2021, pp. 130-133), the researchers coded the articles inductively by identifying affordances and constraints generated through the emergency remote teaching. Through this analysis, the researchers gained a set of initial codes that were compared and discussed in a meeting. The meeting was held online and recorded using the videoconferencing tool Zoom. The second author then established a coding book based on the suggested initial codes and discussions by assembling the initial codes into coding categories displaying greater explanatory power (Miles \& Huberman, 1994); additionally, coding categories were thematically grouped, i.e. it was seen that the codes denoting constraints and affordances were related to teachers, students, classroom practices and institutional or governmental aspects. The developed coding categories were checked by the other researchers and refined in another online meeting. After that, the first ten articles were recoded using the established coding categories. Another set of papers was then coded using the coding categories; for this reason, the set was divided into three groups and distributed to the groups of researchers as shown in Table 1. After this round, the previously established coding categories were reviewed, and modifications were realised. For example, the codes belonging to the theme institutional/governmental level were changed in order to consider that governmental support may be given to schools, teachers or students. Taking these modifications into account, the data that had been analysed was re-analysed when it included content referring to the institutional or governmental level. After each round of analysis, the two researchers who analysed the same set of data met online and discussed their results. In cases of disagreement or uncertainty, the third researcher was consulted. The remaining articles were analysed in the same way. These data analysis procedures were conducive to gaining familiarity with the data, enhancing the validity of the coding categories and establishing inter-rater reliability as the whole process of data analysis was subject to a critical negotiation. The coding categories are shown in Appendix 2.

Throughout the study, the results of the data analysis were charted in an excel file managed by the first researcher. This file contained bibliographic information, the information about research methodology, contexts and participants as well as the coding categories identified in each article. In addition to the codes, notes and remarks were kept documenting peculiarities of the articles analysed. The information stored in the excel file was then used in order to summarise and present the results of the study. 


\section{Reporting of the Results}

After finalising the data analysis, the gained results were quantitized (Sandelowski et al., 2009) and displayed in figures. This step aimed at detecting regularities and trends in the literature on the impacts of ERT on foreign or second language teaching. For exemplification purposes, excerpts from the papers analysed were added to the statistical information provided in the figures.

Throughout the data analysis, we came across articles in which concrete solutions are presented such as Wagner (2020) reporting on an alternative form of assessment to address the need to shut down test centres. Since it was not easily possible to code those concrete solutions to address challenges faced during the pandemic by using the established coding categories, we decided to present them in a separate section.

\section{FINDINGS}

This section offers the findings obtained from the analysis as outlined in detail in the previous section. The findings in concern primarily report on the types of published papers and research methods used in the analysed publications, research contexts, the participants involved in the studies, affordances and constraints released in the publications from different aspects (e.g. teacher-related, student-related, classroom-related and governmental/institutional level) and concrete solutions for ERT challenges suggested in the analysed papers.

\section{Types of Published Papers and Research Methods}

After the exclusion of irrelevant papers, 45 publications were analysed. These papers consisted of 24 research papers and 21 reports. Figure 1 gives an overview of the published papers and distinguishes applied research methods in the research papers.

\section{Figure 1.}

Paper Types and Research Methods

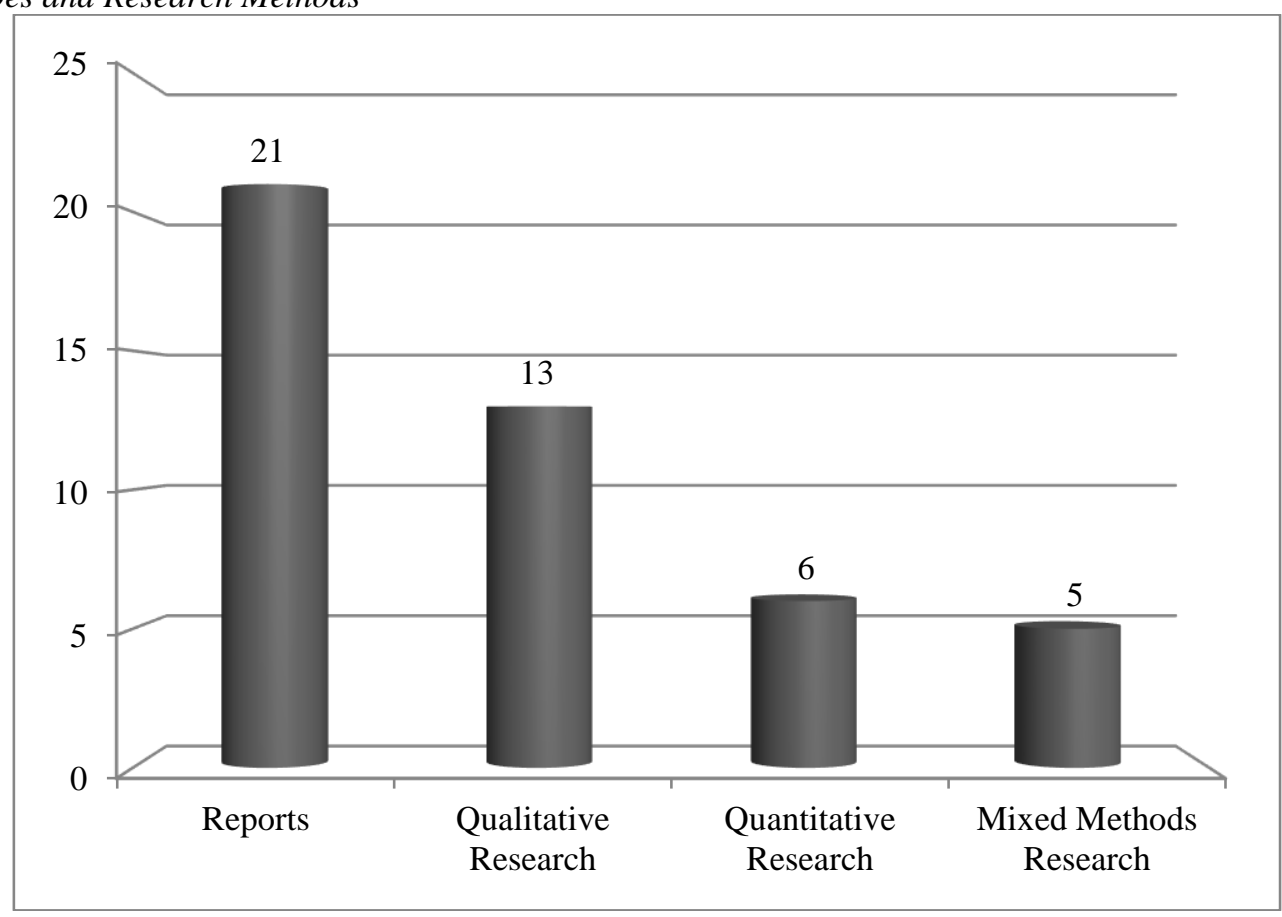


The publication type report (47\% of all papers) refers to papers in which governmental institutions such as authorities (e.g. United States Department of Education, 2020), school districts or university departments report on experiences made during ERT due to the Covid-19 pandemic and provide practical recommendations for teachers, students or administrators, or in which researchers introduce instructional novelties or applications to address challenges triggered by ERT and to increase the efficiency of educational processes (e.g. Guillén et al., 2020). Different from research studies, reports are not based on systematic data collection, and a research methodology is usually not documented in these papers. Additionally, there are reports that refer but are not limited to second or foreign language education. Despite these observations, they were included into the analysis due to their direct connection to ERT as long as they displayed information relevant for the teaching of other languages. As shown in Figure 1, 54\% of the research studies were qualitative in nature while the amount of quantitative and mixed methods studies was almost identical.

\section{Contexts}

For the analysis, two contexts of the papers were examined. For one thing, it was examined in what countries the papers on ERT are located. Another focus was the educational context covered in the publications.

\section{Location}

There are 10 reports that are not related to a specific regional context but intend to provide contextindependent information (e.g. Kohnke \& Moorhouse, 2020, on the applicability of the videoconferencing tool Zoom). The other studies and reports come from 21 countries or locations with one study located in two countries. The distribution is as follows:

13 studies and reports : The USA

2 studies and reports $\quad$ : Bulgaria; Japan; Saudi Arabia

1 study or report $\quad$ : Algeria; Croatia; Chile; Germany; Hong Kong; Indonesia; Ireland; Jordan; Mexico; Oman; Pakistan; Philippines; South Korea; Thailand; Trinidad and Tobago; Turkey; the UK.

While it is expectable that there is a high number of papers coming from predominantly Englishspeaking locations such as the USA, the UK and Hong Kong because the analysis included only papers written in English, it is remarkable that contributions from China are not in the dataset given the fact that the pandemic started from China and that, in general, a high number of papers on language teaching is produced in the Chinese context.

\section{Educational contexts}

Ten publications do not refer to a specific level or field of education. The other papers report findings from or are directed to the fields of education indicated in Figure 2. The classification is based on the educational levels of early childhood education, primary education, secondary education and tertiary education (UNESCO Institute for Statistics, 2012).

Tertiary education is by far the most considered level in the studies and reports analysed followed by K-12 covering the levels ranging from early childhood to secondary education, as portrayed in Figure 2 . 
Figure 2.

Educational Contexts Covered in Papers

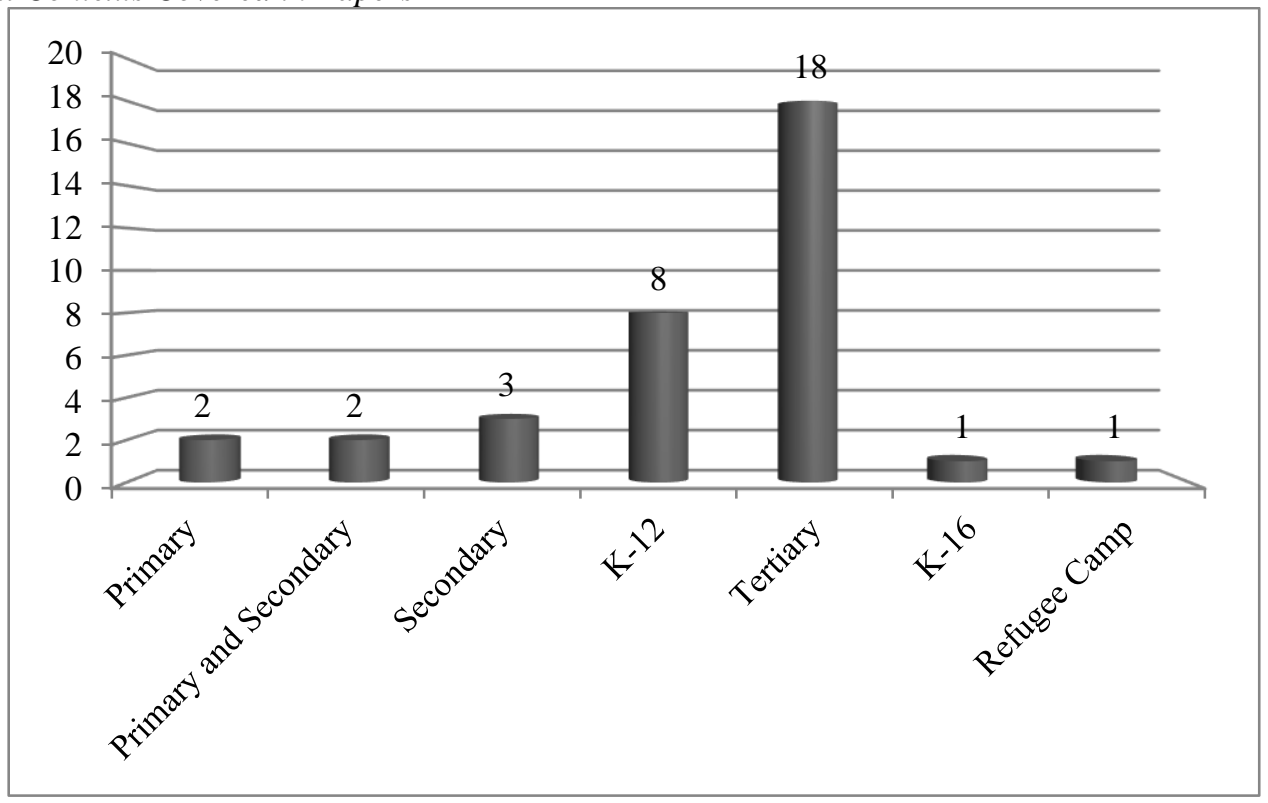

\section{Study Participants}

22 out of the 45 papers report on studies in which data was collected from participants. Figure 3 gives an overview of the participants.

\section{Figure 3.}

Number of Participants in Studies

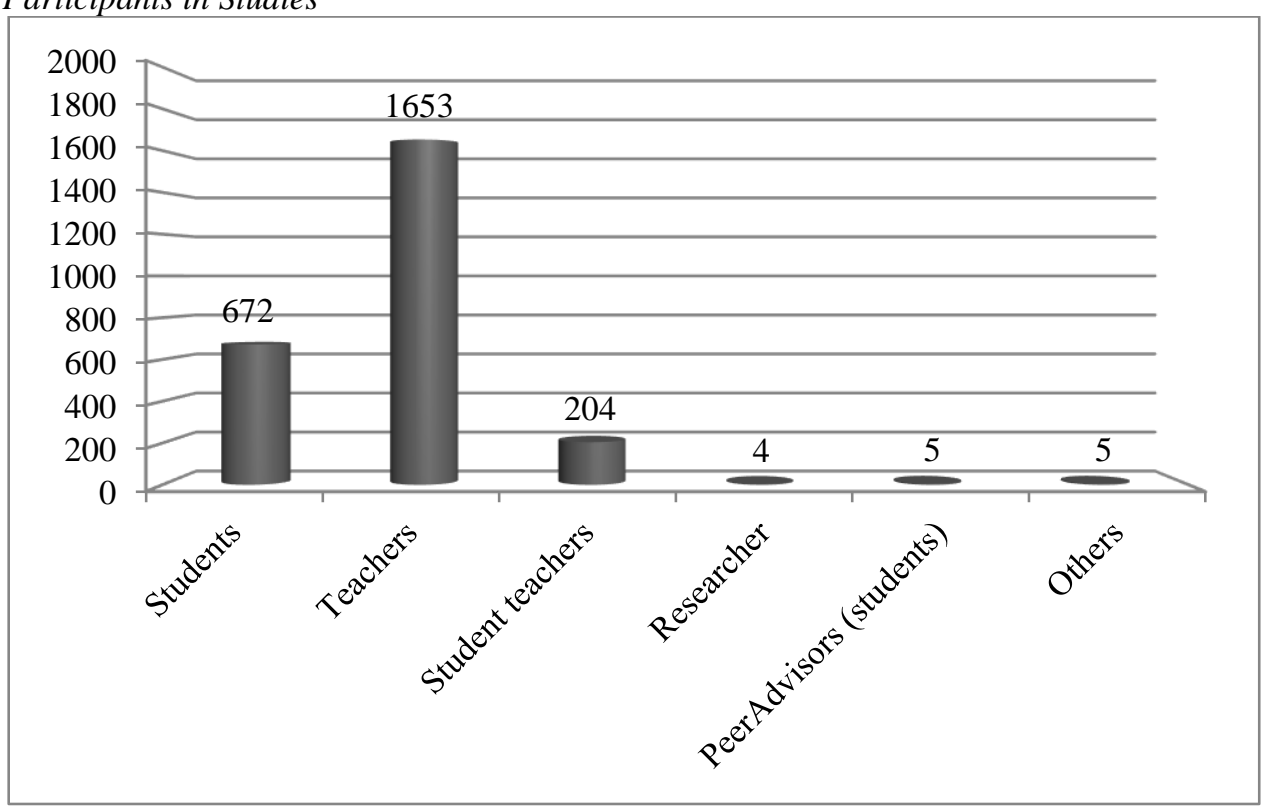

As shown in Figure 3, the group of teachers is the by far most studied group followed by students and student teachers. Only one parent and one school manager (subsumed under others) participated in the studies examined.

To investigate the scale in terms of participant number, distribution of sample sizes was calculated. Figure 4 shows the results for studies in which students participated. 
Figure 4.

Sample Sizes of Studies with Students

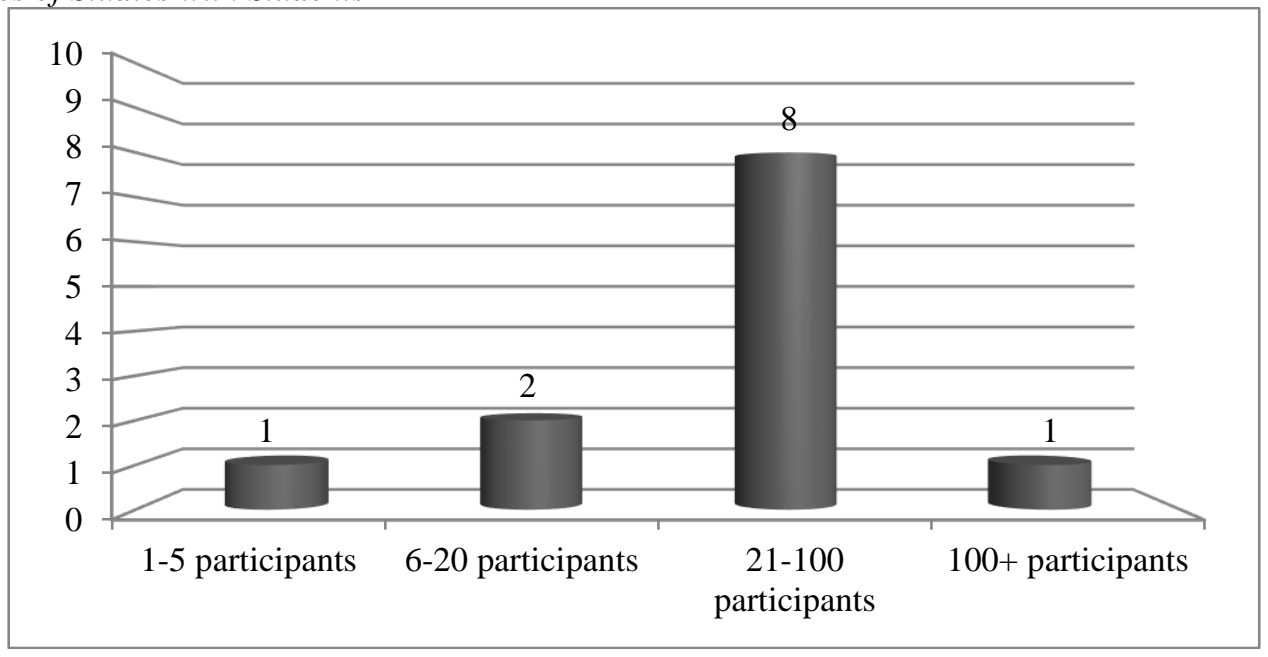

Figure 4 shows that the majority of studies with students as participants were conducted with sample sizes between 21 and 100 (average: 61.6 participants). The results for teachers are shown in Figure 5.

Figure 5.

Sample Sizes of Studies with Teachers

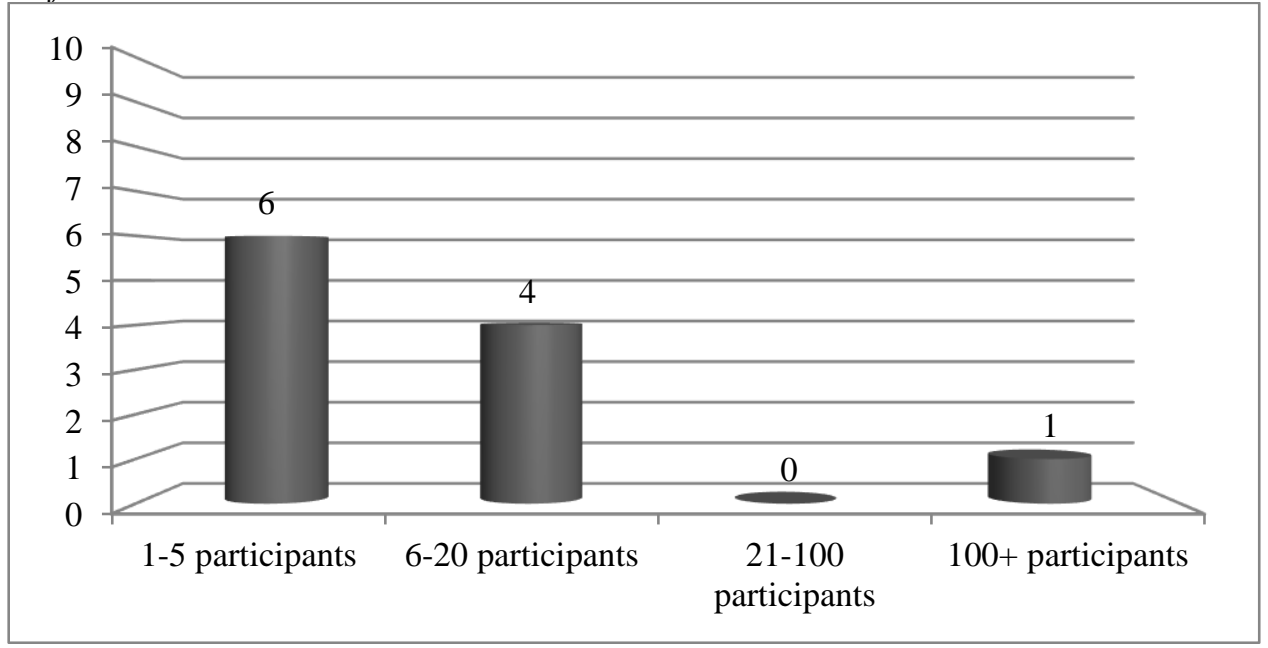

The studies with teachers were mainly small-scale studies, and there was one large-scale study with 1593 participating teachers (Research for Action, 2020), as shown in Figure 5. Two studies were carried out with student teachers (Inpeng \& Nomnian, 2020; Sepulveda-Escobar \& Morrison, 2020); the sample sizes were 177 and 27.

\section{Affordances and Constraints}

The following sections show the findings addressing the second research question. The report of the findings is organised according to the themes that were established as an outcome of the data analysis. First, teacher-related affordances and constraints are reported. Then student-related aspects are shown, followed by classroom-related aspects (i.e. impacts of ERT on instructional practice in class) and aspects concerning the governmental and/or institutional level. In these sections, it is shown in how many publications specific affordances or constraints were mentioned by using the codes developed in the inductive data analysis. Readers are referred to Appendix 2 for operational definitions. The findings are finalised with a section on concrete solutions addressing the challenges posed by the ERT. 


\section{Teacher-related aspects}

The research findings revealed that 28 of the 45 publications addressed ERT practices in foreign/second language education from teacher-related aspects. Some of these publications either reported on how ERT affected the language teachers' practices and professional development or offered recommendations for teachers to fully benefit from ERT practices and to overcome ERTdriven challenges while the other publications falling into this category included both teacher-related outcomes of ERT in foreign/second language education and recommendations for them with a focus on teacher development. The distribution of teacher-related aspects across the analysed articles is displayed in Figure 6.

Figure 6.

Effects of ERT on Teachers

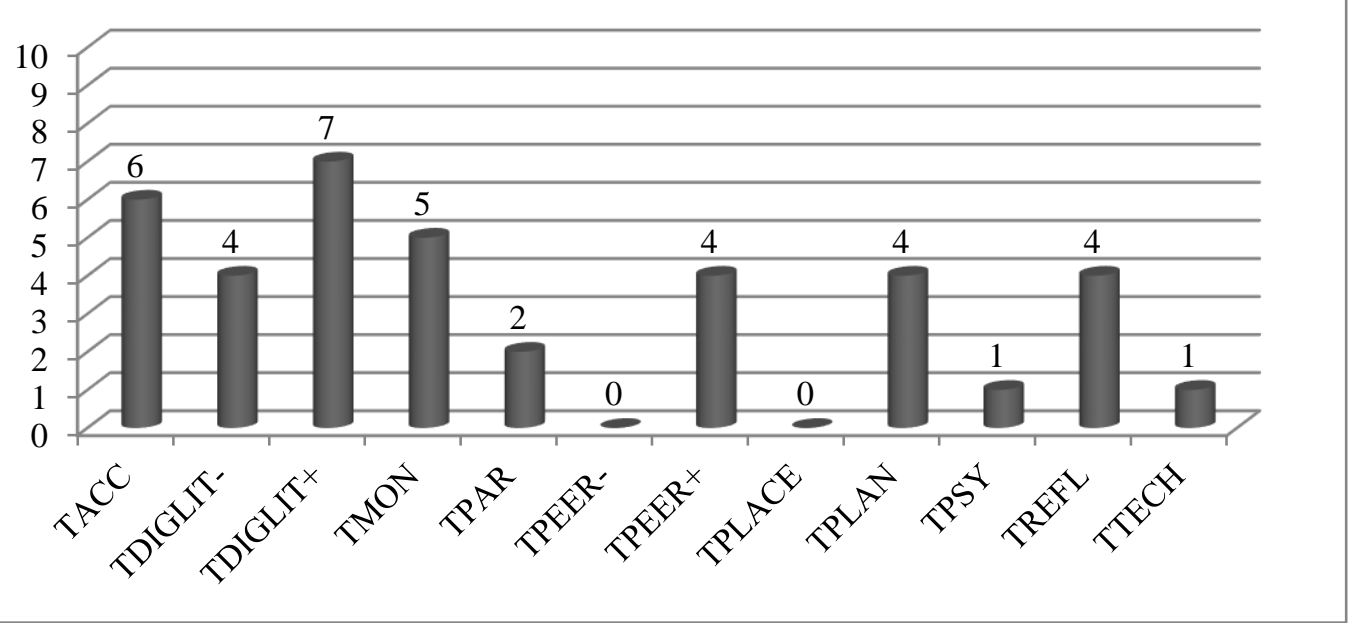

Figure 6 shows that ERT exerts slightly more affordances than constraints on foreign/second language teachers. More specifically, the most frequently reported teacher-related finding is that ERT helps teachers improve their digital literacy skills (TDIGIT+), followed by evidence suggesting that it improves teacher accountability in terms of, for example, creativity, problem solving skills and autonomy (TACC). On the contrary to the former, four studies reported that it constrains teachers due to the lack of or insufficiently developed digital literacy skills (TDIGIT-), which might be considered as a call to increase teachers' digital literacy through institutional or governmental support. Quite in line with this particular finding, the research also indicates that five and four of the analysed publications, respectively, reported on monitoring problems the language teachers experience in assessing students' learning, monitoring the process and evaluating their understanding through giving and receiving feedback (TMON), and challenges they experience when planning and selecting or developing materials (TPLAN). Likewise, two of the publications reported that ERT negatively influences the teacher-parents relations (TPAR). Besides, one of the publications highlighted the insufficient use of ERT by some teachers who have limited access to technical equipment and/or internet (TTECH) and its psychological effects on teachers (TPSY). On the other hand, four of the publications indicated increased collaboration among language teachers to face challenges of ERT (TPEER+), while the opposite was not reported in any publications (TPEER-). In a similar vein, four publications released findings in favour of teachers' reflection on professional issues thanks to ERT practices (TREFL). In sum, while the body of literature indicates that the ERT poses a challenge for language teachers, it also suggests that teachers have developed an awareness of its affordances because

the findings showed that all the participants preferred a formal setting in learning i.e., the use of academic platforms like Moodle to post lectures, activities, and follow the students' assessments (Ghounane, 2020, p. 36). 
Finally, it is significant to note that no study addressed whether the conditions of the teachers' environment impede ERT excluding technical constraints. Hence, this could be evaluated as a research gap to bridge in the field of ERT of foreign/second languages.

The distribution of ERT-based recommendations for foreign/second language teachers generated in the publications is depicted in Figure 7.

\section{Figure 7.}

ERT-Driven Recommendations for Teachers

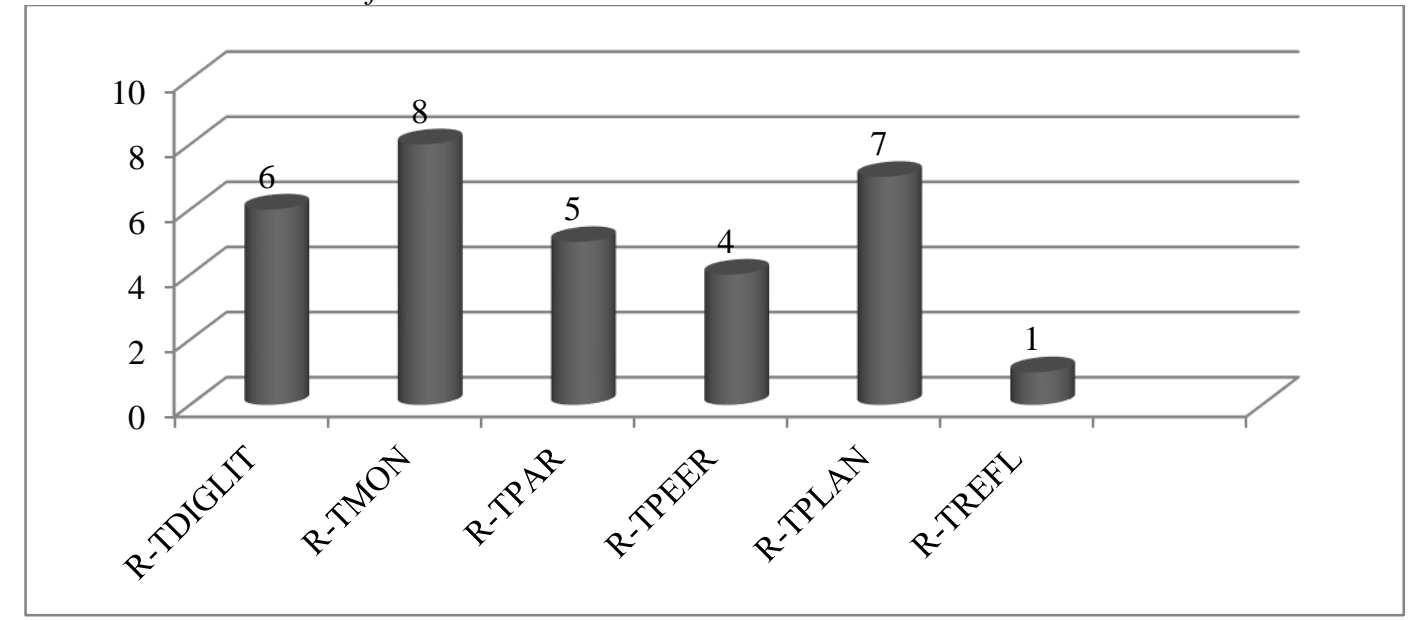

Figure 7 outlines that the publications released ERT-driven recommendations with various foci including monitoring of the educational processes, digital literacy of language teachers and collaboration among these teachers in order to handle the challenges encountered in the process. More specifically, eight publications offer suggestions for the teachers who experience problems in assessing students' learning and evaluating their understanding through giving and receiving feedback in their ERT practices (R-TMON). This is followed by those related to teachers' planning and selecting or developing materials (R-TPLAN), improving digital literacy (R-TDIGIT), teacher accountability (R-TACC), teacher-parent communication (R-TPAR), collaboration between teachers (R-TPEER) and professional reflection (R-TREFL). Recommendations given in the literature vary in terms of providing rather general or more concrete advice. Typical recommendations read: In short (and especially at a time when distance learning is the norm), teachers should be careful
to choose technologies that match the given purpose (Altavilla, 2020, p. 21).

Teachers have to cope with the advancement of technology and language teaching (Ghounane, 2020, p. 38).

Instructors should open a discussion channel with their students in order to become aware of their needs and understand barriers to online learning (Al-Nofaie, 2020, p. 16).

\section{Student-related aspects}

It was revealed that 26 of the 45 publications addressed ERT practices in foreign/second language education with a focus on student-related aspects. As in the case of teacher-related issues, some of these publications either reported on how ERT affected the students' learning practices and development in the target language or offered recommendations for them to fully benefit from ERT practices and to overcome ERT-driven challenges they are faced with while learning the target language whereas the other publications contained both student-related outcomes of ERT in foreign/second language education and recommendations for these students with a focus on foreign/second language development through ERT. The distribution of student-related findings reported in the analysed publications is shown in Figure 8. 
Figure 8.

Effects of ERT on Students

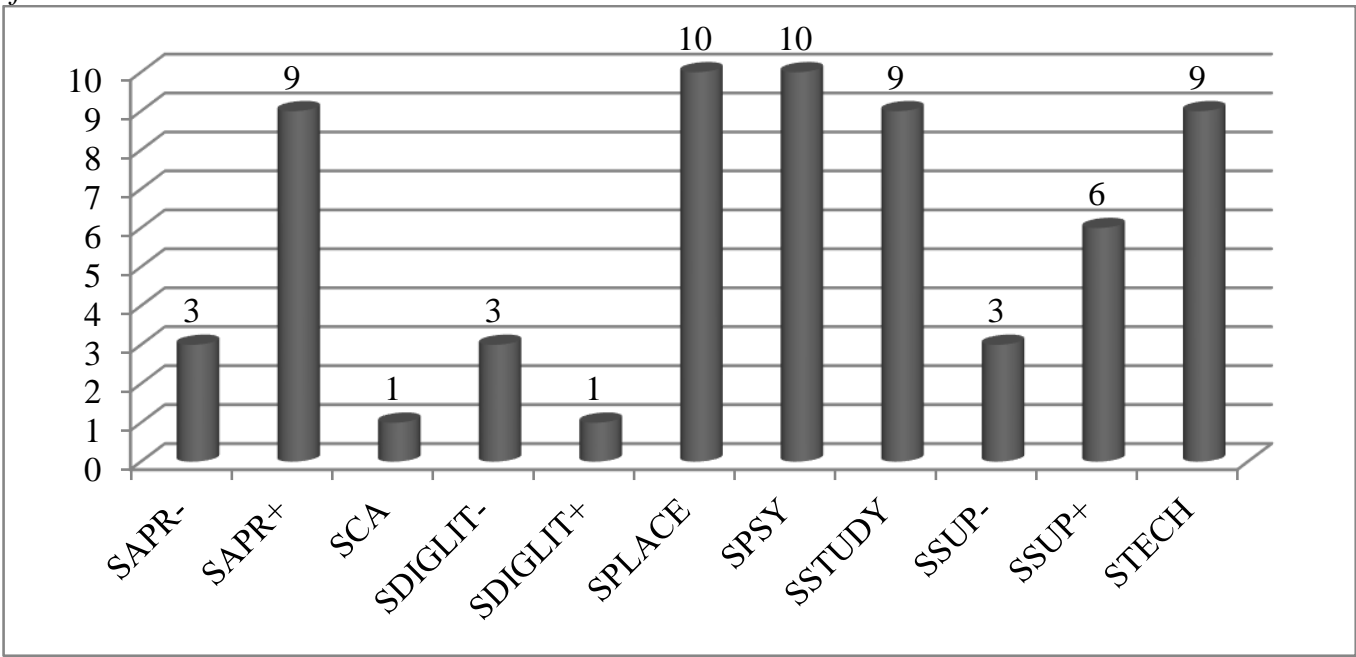

As demonstrated in Figure 8, ERT practices exert more constraints than affordances on foreign/second language students. Namely, ten publications reported that conditions of the students' environment impede ERT (excluding technical constraints) (SPLACE) and that ERT exerts psychological effects on students (SPSY), while nine publications reported that students cannot benefit from ERT sufficiently due to limitations related to technical equipment and/or internet connectivity (STECH). Additionally, ERT was less frequently considered as an opportunity for students to improve their digital literacy (SDIGLIT+) than it was reported to be constraining due to the lack of or insufficiently developed digital literacy (SDIGLIT-). In return, nine publications released findings indicating that ERT improves study skills in terms of, for example, students' creativity, self-directed learning, engagement in activities, problem solving skills and autonomy (SSTUDY). Besides, the publications reporting students' appreciation of instructional practices (SAPR+) remarkably outnumbered those which reported the opposite (SAPR-). Appreciation may be due to specific circumstances when, for example, students do not need to travel arduously to schools (Shahzad et al., 2020) or the new modality is actually advantageous for disabled learners compared to learning in physical classrooms (Svalina \& Ivić, 2020). Lastly, more studies reported that students receive sufficient instructional support from their teachers in ERT (SSUP+) than those reported the opposite (SSUP-). The findings summarised here are exemplified in the following excerpts from the literature:

The students' participation in the forums indicates that the majority of the students have achieved the competency skills, a learning outcome which required students to collaborate with others successfully and use technology effectively (Al-Nofaie, 2020, p. 16).

One interesting finding is that students believed that virtual classes helped them to overcome some learning obstacles, such as fear when they interact in English, while also motivating them to interact with others in English (Alahmadi \& Alraddadi, 2020, p. 68).

But the research that does exist suggests that ELs often encounter challenges related to the accessibility of both hardware and software, the biases baked into those programs (Altavilla, 2020, p. 21).

Older and/or more proficient students could even find or design their own tasks and share them with peers or others, incorporating many of the task engagement facilitators (Egbert, 2020, p. 317).

The distribution of ERT-based recommendations for foreign/second language learners generated in the publications is presented in Figure 9. 
Figure 9.

ERT-Driven Recommendations for Students

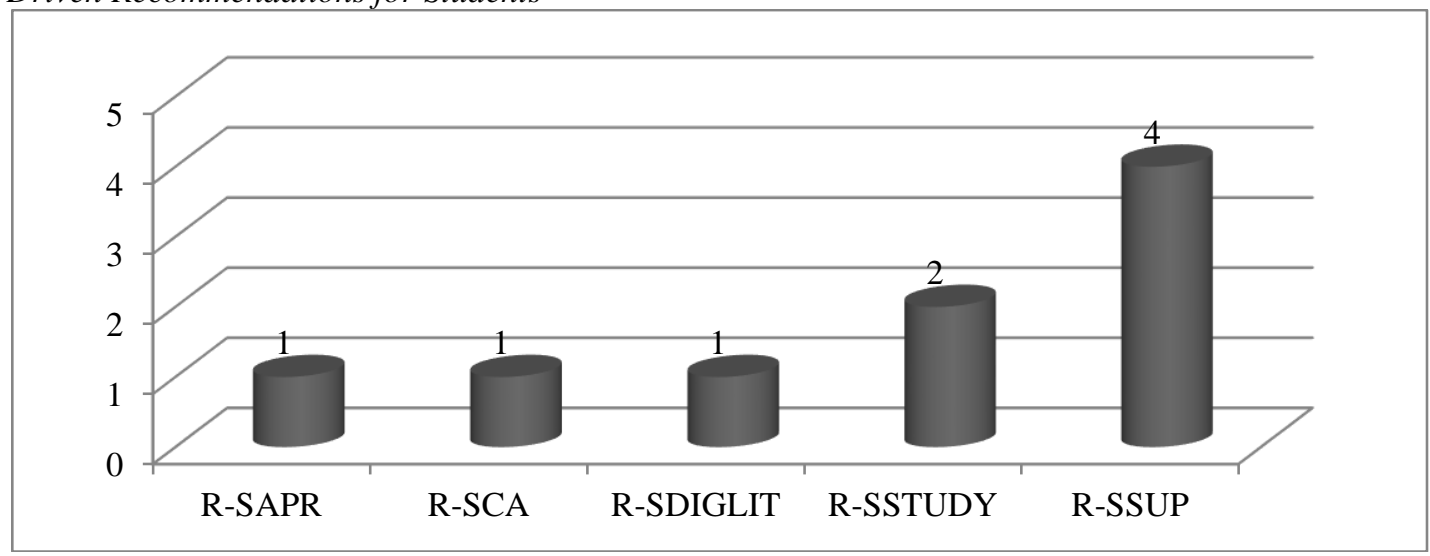

As is suggested in Figure 9, not many studies yielded ERT-based recommendations for foreign/second language learners. The most frequented recommendation points to the need for sufficient instructional support from their teachers in order to fully benefit from ERT (R-SSUP), followed by the recommendations to utilise ERT practices as an opportunity to improve study skills (R-SSTUDY), develop digital literacy skills (R-SDIGLIT), build cultural awareness (R-SCA) and appreciate instructional practices in ERT (R-SAPR). The recommendation to transform the ERT into an opportunity to booster learning is mirrored in the following quotation:

Finally, students should be aware of their responsibility as learners who must spare no efforts when engaging in VLLEs in order to achieve their learning outcomes (Al-Nofaie, 2020, p. 16).

It is significant to note that no recommendations were suggested to overcome the conditions of the students' environment that impede ERT excluding technical constraints and their restricted access to technology and internet in the analysed publications.

\section{Classroom-related aspects}

The findings revealed that 16 of the 45 publications addressed ERT practices in foreign/second language education with a focus on classroom-related aspects. These publications either reported on the modality effects of ERT on instructional practices in online lessons referring but not limited to interaction, skills learning and participation in online lessons and/or generated recommendations related to ERT practices. The distribution of the findings related to classroom-related aspects is given in Figure 10.

Figure 10.

Effects of ERT on Classroom Practices and ERT-Driven Recommendations for Modality

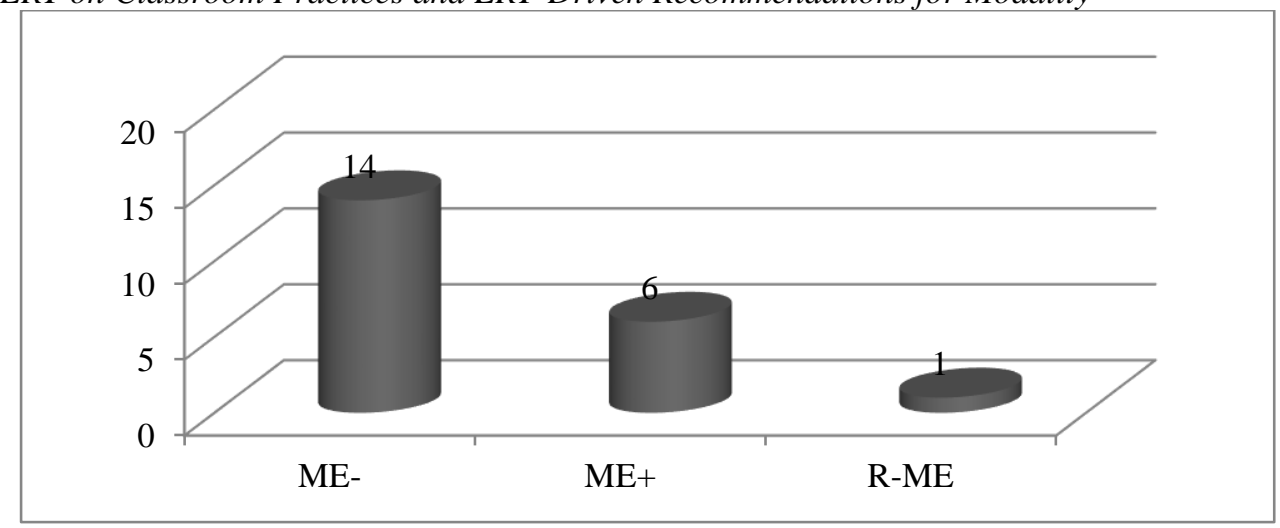


Figure 10 illustrates that the modality has more constraints than affordances related to foreign/second language education. Namely, two third of the publications indicated that ERT negatively affects classroom work while less than one third of them suggested the opposite. Syahrin and Salih (2020) specifically pointing to a negative impact on language teaching report in their study that ERT favours the teaching of receptive skills while it does not provide sufficient opportunities for language learners to engage in language production. The following findings are taken from two studies aiming at investigating the situation of EFL teaching and learning in the Algerian context (Ghounane, 2020) and eliciting public school teachers' use of digital tools in lesson planning, actual practice and assessment (Research for Action, 2020).

In the Algerian context, teachers think that the use of SNS, mainly Facebook in learning is not useful and effective in language learning since learning a foreign language, needs face-to face interaction (Ghounane, 2020, p. 27).

Overall, fewer teachers found online tools to be effective for teaching Dual-Language Learners and students with Individualized Education Plans (IEPS) than teaching students overall (Research for Action, 2020, p. 1).

Two other studies carried out with the purposes investigating the perceptions of language learners on ERT in Saudi Arabia (Al-Nofaie, 2020) and in Pakistan (Shahzad et al., 2020) revealed positive influences of the modality change on ERT foreign/second language education.

Interestingly, it was found that the forums were helpful for shy learners who used to hesitate when participating in class (Al-Nofaie, 2020, p. 14).

In this way, the majority of the students can take advantage of attending the lectures (Shahzad et al., 2020, p. 9).

Finally, it is seen that one of the analysed publications released an ERT-driven recommendation at the classroom level: "In addition to keeping learners' spirits up and their achievement moving forward, using engaging tasks can also help to keep teachers engaged and demonstrating positive attitudes, too" (Egbert, 2020, p. 318).

\section{Aspects concerning the governmental and/or institutional level}

It was revealed that the addressed ERT practices in foreign/second language education were investigated with a focus on aspects at the governmental and/or institutional level in 12 of the analysed 45 publications. Figure 11 shows the distribution of the findings reporting on the effects of ERT on teachers and students at the governmental/institutional level across the analysed publications.

Figure 11.

Effects of ERT on Teachers and Students at Governmental/Institutional Level

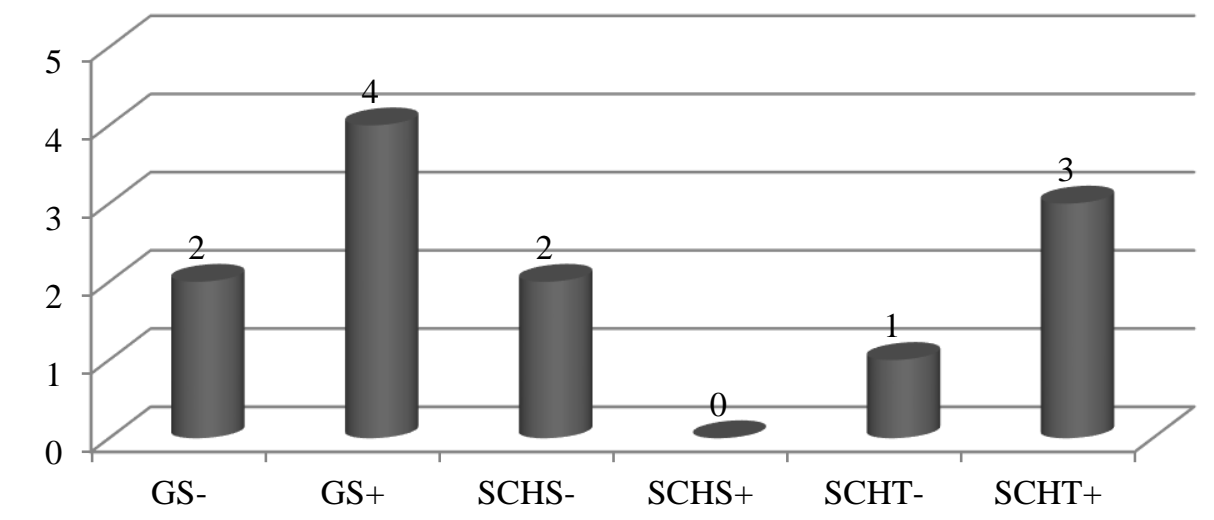


Figure 11 shows that ERT practices of foreign/second language education have not been sufficiently investigated at the governmental or institutional level as aspects belonging to this theme were only covered twelve times in the publications analysed. Nonetheless, the findings indicate that support from the superior government agency (GS+) to schools or language teachers and support from schools to teachers $(\mathrm{SCHT}+)$ are more frequently reported than lack of or insufficient support. Examples for governmental support are documented in the South Korean context with measures taken from the Ministry of Education (Yi \& Jang, 2020) or in Algeria:

Algeria is trying to promote e-learning through creating educational platforms, and training teachers to cope with advances in teaching and technology (Ghounane, 2020, p. 38).

Figure 11 also shows that no or insufficient school precautions helping learners address challenges of ERT are reported in two studies (SCHS-) and sufficient school help for students (SCHS+) is not reported in any of the publications analysed.

Figure 12 displays the distribution of the findings related to ERT-driven recommendations for foreign/second language education at the governmental/institutional level across the analysed publications.

Figure 12.

ERT-Driven Recommendations for Governments/Institutions

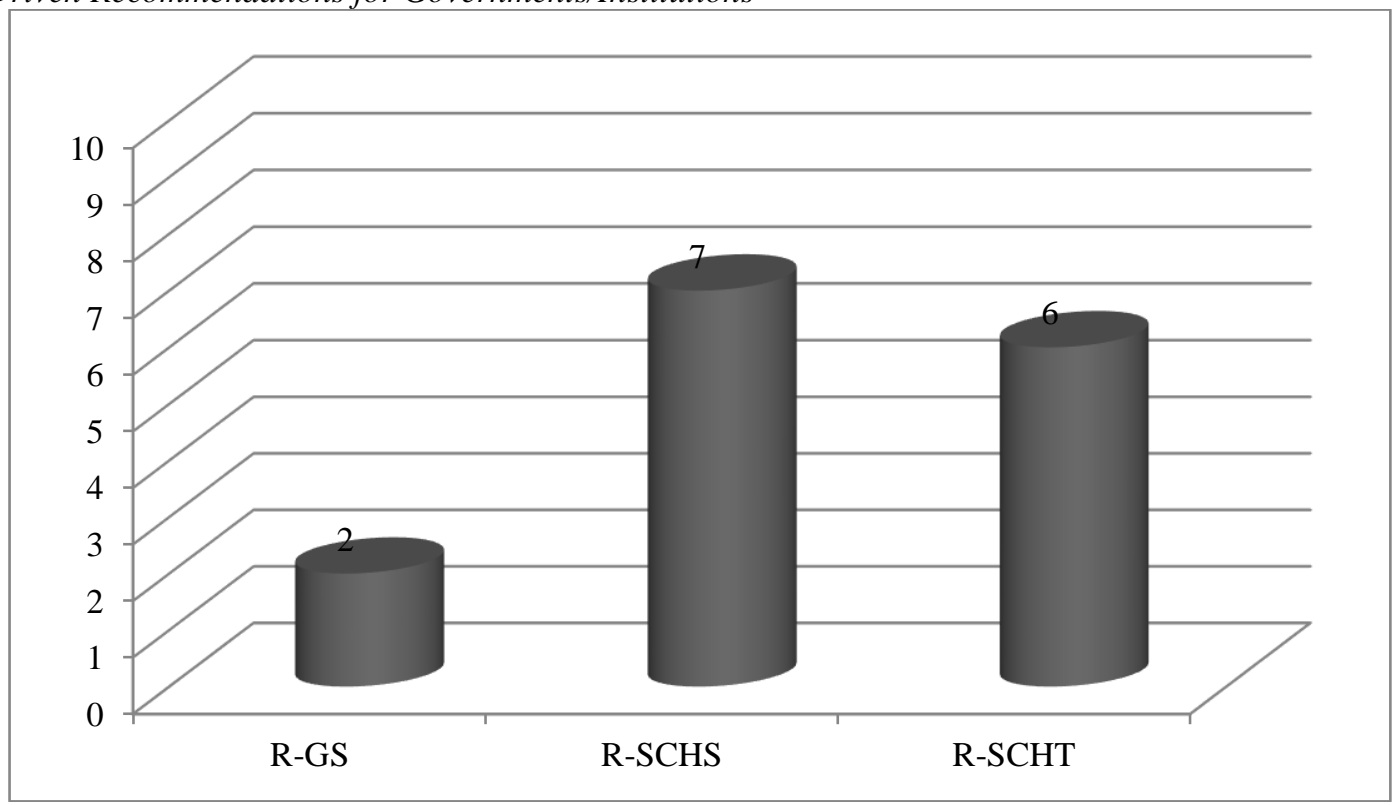

As shown in Figure 12, the analysed publications generated more recommendations in the form of precautions that should be taken by schools to help foreign/second language learners overcome challenges of ERT (R-SCHS) than that of providing professional support and development for foreign/second language teachers to address challenges of ERT (R-SCHT). The following excerpts from two different studies document recommendations of such kind.

State education leaders must provide explicit guidance and criteria for serving DLLs/ELs in hybrid and distance learning (e.g., grade-level standards and developmentally-appropriate materials, synchronous time when students engage with teachers in real time, etc.) (Education Trust West, 2020, p. 5).

At the same time, administrators should ensure that students and teachers have access to technology that promotes social interaction among ELs and their more English-proficient peers (Altavilla, 2020, p. 21). 
Last but not least, two studies released recommendations for schools to receive support from the superior government agency (R-GS) in order to fully benefit from ERT practices in foreign/second language education as well as to handle challenges encountered during teaching. The following recommendation is taken from Inpeng and Nomnian (2020) who analysed Thai pre-service EFL teachers' and teacher trainers' views on the use of Facebook in a TEFL program based on the TPACK framework.

Third, but no less important, a comprehensive digital infrastructure, and training in ICT and the use of social media applications for education is essential, requiring investment, on-going development and sustainment in order to enhance equitable quality education for all teachers and students, especially in remote areas (Inpeng \& Nomnian, 2020, p. 385).

All in all, the ERT-based recommendations generated at the governmental/institutional level were reported much less frequently in the analysed publications (27\%) than those reported for foreign/ second language teachers (57\%) and more frequently than those reported for foreign/second language students $(16 \%)$.

\section{Concrete solutions for ERT challenges}

Some papers reviewed in our study reported on concrete projects, procedures and measures to address the challenges posed by the need to switch to ERT. Different from recommendations, these solutions introduced in the papers provide language teachers, school managers, curriculum planners and learners with concrete instructions for action as they are presented in the form of developed applications. The solutions identified were allocated to three themes: student-directed solutions, teacher-directed solutions and assessment-directed solutions. Table 2 gives an overview of the student-directed solutions identified in the literature.

Table 2.

Student-Directed Solutions Reported in the Literature

\begin{tabular}{|c|c|c|}
\hline Solutions reported & Short description & Sources \\
\hline Advising sessions & $\begin{array}{l}\text { Language and/or learning advisers provide students } \\
\text { (individually or group-based) with remote advising lessons } \\
\text { in which various topics encompassing but not limited to } \\
\text { challenges of ERT, learning tasks and procedures, } \\
\text { individual problems are covered. }\end{array}$ & $\begin{array}{l}\text { Davies et al. (2020); Navarro Cira } \\
\text { and Carillo López (2020); Ohara } \\
\text { and Ishimura (2020); Ross and } \\
\text { DiSalvo (2020) }\end{array}$ \\
\hline $\begin{array}{l}\text { Student-led learning } \\
\text { communities }\end{array}$ & $\begin{array}{l}\text { To reduce restricted opportunities to engage in peer } \\
\text { learning and to strengthen social connections, students meet } \\
\text { in online sessions to work on tasks or share problems faced } \\
\text { due to ERT, engage in collaborative learning opportunities } \\
\text { (e.g. tandem learning) or benefit from communication } \\
\text { channels with academic teachers or other community } \\
\text { members }\end{array}$ & $\begin{array}{l}\text { Davies et al. (2020); Guillén et al., } \\
\text { (2020); Lomicka (2020) }\end{array}$ \\
\hline Self-access learning & $\begin{array}{l}\text { Schools provide learners with portals from which they can } \\
\text { receive supplementary resources to support their own } \\
\text { learning. }\end{array}$ & $\begin{array}{l}\text { Guban-Caisido (2020); Mideros } \\
(2020)\end{array}$ \\
\hline $\begin{array}{l}\text { Incorporation of } \\
\text { digital tools }\end{array}$ & $\begin{array}{l}\text { Complementing synchronous online lessons, digital tools } \\
\text { (e.g. Mobile-assisted learning }[M A L L] \text { ) are integrated to } \\
\text { deepen and broaden language learners' target language } \\
\text { experience }\end{array}$ & Guillén et al. (2020) \\
\hline
\end{tabular}

The student-directed solutions, as shown in Table 2, suggest pathways to cope with constraints posed by ERT by establishing teacher-learner or learner-learner interaction and fostering learner autonomy. Another focus is on the development of the learners' digital literacy. The attempt to establish or maintain communication channels such as advising sessions and student-led learning communities is also apparent in the teacher-directed solutions shown in Table 3. 
Table 3.

Teacher-Directed Solutions Reported in the Literature

\begin{tabular}{lll}
\hline Solutions reported & Short description & Sources \\
\hline Lesson sequence model & 3-stage lesson sequence: pre-live lesson talk (offline), live & Moorhouse and \\
& lesson (video conferencing), post-live lesson talk (learning & Beaumont (2020) \\
& management system) & \\
Synchronous Online Flipped & Sequence of asynchronous and synchronous components to & Marshall and Kostka \\
Learning Approach (SOFLA) & ensure more efficient online teaching & (2020) \\
Online synchronous meeting & Through a variety of functions to establish an interactive & Kohnke and Moorhouse \\
tool (Zoom) & learning environment, Zoom opens opportunities for & (2020) \\
& communicative language teaching; additional features & \\
& allow teachers to document online lessons, receive & \\
& feedback and combine it with other online tools; however, & \\
& spoken interaction in F2F classes appears advantages due to & \\
& modality effects (reduced availability of paralinguistic & \\
& cues, challenging self-nomination, fatigue). & Taguchi (2020) \\
Teaching and learning of & Solutions offered to teach pragmatics: & \\
pragmatics & - structured digital spaces: websites, instructor-designed & \\
& digital games; & \\
& - semi-structured digital spaces: computer-mediated & \\
& communication with a learning partner & \\
& - unstructured digital spaces: authentic online communities & \\
(Wold of Warcraft) social networking sites (Facebook) & \\
Professional online & Establishing sustainable and ongoing collaborative teacher \\
development groups to develop teacher digital literacy, & Knight (2020); Lomicka \\
& (2020); Ross and \\
& reflect on professional practice, share experiences, establish & DiSalvo (2020) \\
& networks & \\
\hline
\end{tabular}

As seen in Table 3, the solutions identified in the papers intend to compensate for negative impacts on instructional practice due to the impossibility to meet physically by offering procedures that benefit from different components and modalities such as digital tools and sequenced lesson models. A further area covered is the professional development of teachers in order to provide teachers with opportunities to exchange experiences made in ERT, to reflect on them and to generate solutions without being forced to depend on top-down approaches that may not meet the demands of a specific teaching context. The last theme that emerged from the data analysis was assessment. Solutions addressing this theme are presented in Table 4.

Table 4.

Assessment-Directed Solutions Reported in the Literature

\begin{tabular}{|c|c|c|}
\hline Solutions reported & Short description & Sources \\
\hline At home test & $\begin{array}{l}\text { Duolingo English Test (DET): at home test as a response to the fact that test } \\
\text { centres (e.g. TOEFL) are shut down due to Covid-19; test used for university } \\
\text { admission }\end{array}$ & Wagner (2020) \\
\hline $\begin{array}{l}\text { Provisional } \\
\text { screening protocols }\end{array}$ & $\begin{array}{l}\text { Provisional screening protocols and interview questions to evaluate language } \\
\text { students' needs under ERT conditions (K-12 English learners with different } \\
\text { home language) }\end{array}$ & $\begin{array}{l}\text { The Council of Great } \\
\text { City Schools (2020) }\end{array}$ \\
\hline
\end{tabular}

As seen in Table 4, two studies address the fact that ERT necessitates a change in the administration of assessment and evaluation. Wagner (2020) critically reviews an alternative to standardised tests that require test takers to be present in test centres, while The Council of Great City Schools (2020) provides precise instructions on how to evaluate learners for placement purposes.

\section{DISCUSSION}

This study reviewed the literature on the impact of ERT due to the Covid-19 pandemic on foreign/second language teaching as evidenced in publications indexed in WoS and ERIC between 1 January and 28 October 2020. The analysis covered formal characteristics of the literature and affordances and constraints reported in the papers analysed. 
The analysis revealed, for one thing, that a large part of the body of literature currently available consists of reports presented by practitioners, i.e. schools, governmental authorities and educational foundations, and research studies. The reports examined in this study are definitely informative and valuable because they allow us to picture the reality of ERT in foreign/second language teaching, especially for English learners in the USA with a different home language, based on the observations of practitioners. However, there is a need for more research studies that do not rely on insider observation but on methodologically validated data collection and analysis procedures. In particular, more quantitative studies on students with greater sample sizes will provide us with more generalisable results (Creswell, 2009). Furthermore, a predominance of papers from the USA has been observed in our study. Taking into consideration that the language of the papers was English, it is not surprising to see a majority of papers from English-speaking countries. However, publications covering a wider range of countries are desirable.

The educational context most frequently covered in the papers is the tertiary level. We can assume that this context is by far the most accessible to researchers, who, usually employed at universities, can research their own working environment; however, more research on the impact of ERT on especially young learners is desirable considering that young learners are especially vulnerable to ERT (Parker et al., 2020).

The affordances and constraints identified in the studies accord with the results gained in studies in different educational domains (e.g. Ferri et al., 2020; Petillion \& McNeil, 2020; Whittle et al., 2020). It is an interesting finding of our study that the publications analysed report slightly more affordances for teachers than constraints. In a similar vein, the literature shows a neither entirely positive nor entirely negative picture of the effects of ERT on language learners. The findings indicate that both teachers and students are able to turn challenges of ERT into affordances when they receive sufficient support from governmental authorities, schools or peers and benefit from already acquired digital skills and technical infrastructure available (Mbiydzenyuy \& Silungwe, 2020; Robinson et al., 2020). In that sense, the situation of ERT may contribute to the professional growth of teachers in terms of both improving digital literacy skills and pedagogic skills and of learners in terms of developing academic skills (Ferri et al., 2020; Syahrin \& Salih, 2020). On the whole, however, it should be considered that the body of literature tends to report examples of 'good practices'; they are valuable because they inform other contexts on how to deal with the challenges of ERT. However, negative impacts of ERT on language teaching contexts may simply be underrepresented given the dramatic consequences the pandemic has had on education worldwide (Bozkurt et al., 2020). A strong indicator for this assumption is that classroom practices rather appear to be negatively influenced by the novel situation. What can be clearly stated is that we do not have enough studies on what instructional practice actually looks like, i.e. there is a need for studies analysing, for example, classroom management and classroom discourse in classes benefitting from videoconferencing tools. Altavilla (2020), referring to her context, states: "As yet, however, there has been relatively little research into effective technology-based instruction for ELs in U.S. schools" (p. 21). This evaluation applies for second/foreign language teaching under ERT conditions in general.

\section{CONCLUSIONS}

Based on the findings of this study, it can be concluded that the effectiveness of ERT of other languages is enhanced when teachers are provided with professional development enabling them to more skilfully employ digital literary skills and to adapt their pedagogic skills to the remote learning environment. In the same way, students should be supported in using digital tools. This encompasses governmental and school support in terms of technical help and equipping participants with devices to participate in online learning. A significant factor in the support for teachers and students is the establishment of channels for communication so that problems can be shared and measures can be taken to motivate students and teachers. 
While such measures undoubtedly serve as an ad hoc response to faced challenges in ERT, there is a need to develop context-compatible pedagogies by critically evaluating local implementations of teaching programmes that consider the need to deliver instruction in ERT. Such pedagogies may inform teachers on how to support students who apparently cannot deal with the challenges of ERT in spite of available digital literacy. The task is to benefit from existing digital skills available for learners and to redirect them so that they can develop their own strategies to more fully participate in classroom interaction and, consequently, language learning. Additionally, schools should develop forms of institutionalised counselling that advises learners on how to prolong engagement in learning beyond online lessons and to overcome or at least lighten psychological problems caused by the lack of mobility and in-class contact. Directed towards the professional and personal development of language teachers, emergent pedagogies will address the need to train teachers in the design and use of online resources conducive to language learning in ERT. Such training can be given by experts or in teacher communities in which practitioners share experiences and ideas. Finally, ERT forces teacher education programme developers to revise curricula to qualify digitally literate teachers. The task is not only to teach pre-service teachers how to implement technology as an alternative array to support in-class teaching but also to equip them with the expertise to use technology when in-class delivery of instruction is no option as in the Covid-19 pandemic. Stating this need, it is probably not unrealistic to believe that teacher educators themselves need to gain or develop competences necessary to address the specific needs of ERT in teacher education. Research focusing on the aspects outlined here will not only contribute to solutions to face the challenges of ERT in second/foreign language teaching but will also help theorise ERT-directed pedagogies.

The current research was limited to the review of the publications on Covid-19 driven ERT practices in foreign/second language education released over a limited period of time. Further studies should be conducted to review publications that report on similar practices in teaching of different disciplines (e.g. mathematics, engineering, medicine and business). The authors hope that this study, apart from informing about early research on ERT in second/foreign language teaching, provides methodological guidance on how to conduct this kind of research in any educational domain.

\section{Acknowledgement}

The preliminary findings of this study were orally presented with the title "Emergency remote education due to Covid-19 in teaching other languages. The state of research, insights and gaps" at "EDUCCON 2020 Empower Teaching" on 12 December 2020.

\section{REFERENCES}

Note: The studies included in the document analysis are marked with an asterisk.

*Alahmadi, N. S., \& Alraddadi, B. M. (2020). The impact of virtual classes on second language interaction in the Saudi EFL context: A case study of Saudi Undergraduate students. Arab World English Journal, 11(3), 56-72. https://dx.doi.org/10.24093/awej/vol11no3.4

*Al-Nofaie, H. (2020). Saudi University students' perceptions towards virtual education during Covid 19 pandemic: A case study on language learning via blackboard. Arab World English Journal, 11(3), 4-20. https://dx.doi.org/10.24093/awej/vol11no3.1

*Altavilla, J. (2020). How technology affects instruction for English learners. Phi Delta Kappan, 102(1), 18-23. https://doi.org/10.1177/0031721720956841

Atkins, D. E., Brown, J. S., \& Hammond, A. L. (2007). A review of the open educational resources (OER) movement: Achievements, challenges, and new opportunities (Vol. 164). Mountain View: Creative common.

*Atmojo, A. E. P., \& Nugroho, A. (2020). EFL classes must go online! Teaching activities and challenges during COVID-19 pandemic in Indonesia. Register Journal, 13(1), 49-76. https://doi.org/10.18326/rgt.v13i1.49-76 
Beldarrain, Y. (2006). Distance education trends: Integrating new technologies to foster student interaction and collaboration. Distance education, 27(2), 139-153. https://doi.org/10.1080/01587910600789498

*Billings, E., \& Lagunoff, R. (2020). Supporting English learners during school closures: considerations for designing distance learning experiences. Crisis response resource. WestEd. Retrieved November 31, 2020 from https://files.eric.ed.gov/fulltext/ED605945.pdf

Bowen, G. A. (2009). Document analysis as qualitative research method. Qualitative Research Journal 9(2), 2740. https://doi.org/10.3316/QRJ0902027

Bozkurt, A., Jung, I., Xiao, J., Vladimirschi, V., Schuwer, R., Egorov, G., Lambert, S. R., Al-Freih, M., Pete, J., Olcott, D., Jr., Rodes, V., Aranciaga, I., Bali, M., Alvarez, A. V., Jr., Roberts, J., Pazurek, A., Raffaghelli, J. E., Panagiotou, N., de Coëtlogon, P., . . Paskevicius, M. (2020). A global outlook to the interruption of education due to COVID-19 pandemic: Navigating in a time of uncertainty and crisis. Asian Journal of Distance Education, 15(1), 1-126. https://asianjde.org/ojs/index.php/AsianJDE/article/view/462

Coley, R., Cradler, J., \& Engel, P. K. (1997). Computers and Classrooms: The Status of Technology in US Schools. Policy Information Report.

Collins, A., \& Halverson, R. (2018). Rethinking education in the age of technology: The digital revolution and schooling in America. Teachers College Press.

Creswell, J. W. (2009). Research design: Qualitative, quantitative, and mixed methods approaches ( ${ }^{\text {rd }}$ ed.). Sage.

*Davies, H., Wongsarnpigoon, I., Watkins, S., Vola Ambinintsoa, D., Terao, R., Stevenson, R., Imamura, Y., Edlin, C., \& Bennett, P. A. (2020). A self-access center's response to COVID-19: Maintaining stability, connectivity, well-being, and development during a time of great change. Studies in Self-Access Learning Journal, 11(3), 135-147. https://doi.org/10.37237/110304

*Doncheva, L., Spasova, I., \& Georgiev, M. (2020). Sports students' satisfaction with their foreign language studies during the outbreak of Ccovid-19. Pedagogy, 92(7s), 268-279. Retrieved December 10, 2020 from https://www.ceeol.com/search/article-detail?id=901745

*Dubreil, S. (2020). Using games for language learning in the age of social distancing. Foreign Language Annals, 53(2), 250-259. https://doi.org/10.1111/flan.12465

*Education Trust West (2020). A Vision for California's schools this fall: Equity for dual language and English learners in an unprecedented moment. https://files.eric.ed.gov/fulltext/ED607554.pdf

*Egbert, J. (2020). The new normal?: A pandemic of task engagement in language learning. Foreign Language Annals, 53(2), 314-319. https://doi.org/10.1111/flan.12452

Ferri, F., Grifoni, P., \& Guzzo, T. (2020). Online learning and emergency remote teaching: Opportunities and challenges in emergency situations. Societies, 10(4), 86. https://doi.org/10.3390/soc10040086

Fray, L., \& Gore, J. (2018). Why people choose teaching: A scoping review of empirical studies. Teaching and Teacher Education, 75, 153-163. https://doi.org/10.1016/j.tate.2018.06.009

*Gacs, A., Goertler, S., \& Spasova, S. (2020). Planned online language education versus crisis-prompted online language teaching: Lessons for the future. Foreign Language Annals, 53(2), 380-319. https://doi.org/10.1111/flan.12460

*Gallardo, V. M., Finnegan, P., Ingram, A., \& Martin, S. (2020). Supporting multilingual/English learners during school closures. Washington Office of Superintendent of Public Instruction. Retrieved November 31, 2020 from http://files.eric.ed.gov/fulltext/ED606049.pdf

*Ghounane, N. (2020). Moodle or social networks: What alternative refuge is appropriate to Algerian EFL students to learn during Covid-19 pandemic. Arab World English Journal, 11(3), 21-41. https://dx.doi.org/10.24093/awej/vol11no3.2

Grant, M. J., \& Booth, A. (2009). A typology of reviews: an analysis of 14 review types and associated methodologies. Health Information and Libraries Journal, 26(2), 91-108. https://doi.org/10.1111/j.14711842.2009.00848.x

*Guban-Caisido, D. A. D. (2020). Language advising as psychosocial intervention for first time self-access language learners in the time of COVID-19: Lessons from the Philippines. Studies in Self-Access Learning Journal, 11(3), 148-163. https://doi.org/10.37237/110305

*Guillén, G., Sawin, T., \& Avineri, N. (2020). Zooming out of the crisis: Language and human collaboration. Foreign Language Annals, 53, 320-328. https://doi.org/10.1111/flan.12459

Hew, K. F., \& Brush, T. (2007). Integrating technology into K-12 teaching and learning: Current knowledge gaps and recommendations for future research. Educational Technology Research and Development, 55(3), 223-252. https://doi.org/10.1007/s11423-006-9022-5

Hodges, C., Moore, S., Lockee, B., Trust, T., \& Bond, A. (2020). The difference between emergency remote teaching and online learning. Educause Review. Retrieved December 5, 2020 from https://er.educause.edu/articles/2020/3/the-difference-between-emergency-remote\%20teaching-andonline-learning 
*Hristakieva, T. (2020). Kinezitherapy Students' Attitude to Foreign Language Learning in Pandemic Conditions. Педагогика, 92(7s), 252-259. Retrieved December 10, 2020 from https://www.ceeol.com/search/article-detail?id=901738

Hung, H. T., Yang, J. C., Hwang, G. J., Chu, H. C., \& Wang, C. C. (2018). A scoping review of research on digital game-based language learning. Computers \& Education, 126, 89-104. https://doi.org/10.1016/j.compedu.2018.07.001

*Inpeng, S., \& Nomnian, S. (2020). The use of Facebook in a TEFL program based on the TPACK framework. LEARN Journal: Language Education and Acquisition Research Network Journal, 13(2), 369-393. https://files.eric.ed.gov/fulltext/EJ1258789.pdf

Kennewell, S. (2001). Using affordances and constraints to evaluate the use of information and communications technology in teaching and learning. Journal of Information Technology for Teacher Education, 10(1-2), 101-116. https://doi.org/10.1080/14759390100200105

*Knight, S. W. (2020). Establishing professional online communities for world language educators. Foreign Language Annals, 53(2), 298-305. https://doi.org/10.1111/flan.12458

*Kohnke, L., \& Moorhouse, B. L. (2020). Facilitating synchronous online language learning through Zoom. RELC Journal. Advance online publication. https://doi.org/10.1177\%2F0033688220937235

Levac, D., Colquhon, H, \& O'Brien, K. (2010). Scoping studies: advancing the methodology. Implementation Science, 5(1), 69. https://doi.org/10.1186/1748-5908-5-69

*Lomicka, L. (2020). Creating and sustaining virtual language communities. Foreign Language Annals, 53(2), 306-313. https://doi.org/10.1111/flan.12456

Long, M. (1983). Inside the "black box'. In H. Seliger \& M. Long (Eds.), Classroom oriented research in second language acquisition (pp. 3-36). Newbury House.

Major, L., \& Watson, S. (2018). Using video to support in-service teacher professional development: the state of the field, limitations and possibilities. Technology, Pedagogy and Education, 27(1), 49-68. https://doi.org/10.1080/1475939X.2017.1361469

*Marshall, H. W., \& Kostka, I. (2020). Fostering teaching presence through the synchronous online flipped learning approach. The Electric Journal for English as a Foreign Language, 24(2). http://teslej.org/pdf/ej94/int.pdf

* Masterson, M. (2020). An exploration of the potential role of digital technologies for promoting learning in foreign language classrooms: Lessons for a pandemic. International Journal of Emerging Technologies in Learning (iJET), 15(14), 83-96. https://doi.org/10.3991/ijet.v15i14.13297

Mbiydzenyuy, N. E., \& Silungwe, D. (2020). Teaching and Learning in resource-limited settings in the face of the COVID-19 pandemic. Journal of Educational Technology \& Online Learning, 3(3), 211-223. https://doi.org/10.31681/jetol.732077

*Mideros, D. (2020). Out-of-class learning of Spanish during COVID-19: A case study in Trinidad and Tobago. Studies in Self-Access Learning Journal, 11(3), 199-219. https://doi.org/10.37237/110308

Miles, M. B., \& Huberman, A. M. (1994). Qualitative data analysis ( $2^{\text {nd }}$ ed.). Sage.

*Moorhouse, B. L., \& Beaumont, A. M. (2020). Utilizing video conferencing software to teach young language learners in Hong Kong during the COVID-19 class suspensions. TESOL Journal, 11(3), e00545. https://doi.org/10.1002/tesj.545

*Motteram, G., Dawson, S., \& Al-Masri, N. (2020). WhatsApp supported language teacher development: A case study in the Zataari refugee camp. Education and Information Technologies, 25(6), 5731-5751. https://doi.org/10.1007/s10639-020-10233-0

Munn, Z., Peters, M. D. J., Stern, C., Tufanaru, C., McArthur, A., \& Aromataris, E. (2018). Systematic review or scoping review? Guidance for authors when choosing between a systematic or scoping review approach. BMC Medical Research Methodology, 18(143). https://doi.org/10.1186/s12874-018-0611-x

*Navarro Cira, B. E., \& Carrillo López, I. (2020). COVID-19, a breakthrough in educational systems: Keeping the development of language learners' autonomy at self-access language centres. Studies in Self-Access Learning Journal, 11(3), 220-234. https://doi.org/10.37237/110309

O'Flaherty, J., \& Phillips, C. (2015). The use of flipped classrooms in higher education: A scoping review. The Internet and Higher Education, 25, 85-95. https://doi.org/10.1016/j.iheduc.2015.02.002

*Ohara, T., \& Ishimura, F. (2020). Emergency remote support at the self-access learning center: Successes and limitations. Studies in Self-Access Learning Journal, 11(3), 235-249. https://doi.org/10.37237/110310

Parker, R., Morris, K., \& Hofmeyr, J. (2020). Education, inequality and innovation in the time of COVID-19. JET Education Services.

Petillion, R. J., \& McNeil, W. S. (2020). Student experiences of emergency remote teaching: Impacts of instructor practice on student learning, engagement, and well-being. Journal of Chemical Education 97(9), 2486-2493. https://doi.org/10.1021/acs.jchemed.0c00733 
Piccoli, G., Ahmad, R., \& Ives, B. (2001). Web-based virtual learning environments: A research framework and a preliminary assessment of effectiveness in basic IT skills training. MIS Quarterly, 401-426. https://doi.org/10.2307/3250989

*Research for Action (2020). Teacher use of digital tools: Results of a survey of district teachers in Philadelphia, Pittsburgh, Scranton and Neshaminy. http://files.eric.ed.gov/fulltext/ED608046.pdf

Robinson, H., Al-Freih, M., Kilgore, W. (2020). Designing with care. Towards a care-centered model for online learning design. The International Journal of Information and Learning Technology, 37(3), 99-108. https://doi.org/10.1108/IJILT-10-2019-0098

*Ross, A. F., \& DiSalvo, M. L. (2020). Negotiating displacement, regaining community: The Harvard Language Center's response to the COVID-19 crisis. Foreign Language Annals, 53(2), 371-379. https://doi.org/10.1111/flan.12463

Ruggiero, D., \& Mong, C. J. (2015). The teacher technology integration experience: Practice and reflection in the classroom. Journal of Information Technology Education: Research, 14, 161-178. Retrieved from http://www.jite.org/documents/Vol14/JITEv14ResearchP161-178Ruggiero0958.pdf

*Russell, V. (2020). Language anxiety and the online learner. Foreign Language Annals, 53(2), 338-352. https://doi.org/10.1111/flan.12461

Saldaña, J. (2021). The coding manual for qualitative researchers ( $4^{\text {th }}$ ed.). Sage.

Sandelowski, M., Voils, C. I., \& Knafl, G. (2009). On quantitizing. Journal of Mixed Methods Research, 3(3), 208-222. https://doi.org/10.1177/1558689809334210

*Sayer, P., \& Braun, D. (2020). The disparate of COVID-19 remote learning on English learners in the United States. TESOL Journal, 11(3), https://doi.org/10.1002/tesj.546

*Schneider, C. (2020). Setting up a language learning environment in Microsoft Teams. Studies in Self-Access Learning Journal, 11(3), 263-270. https://doi.org/10.37237/110312

*Sepulveda-Escobar, P., \& Morrison, A. (2020). Online teaching placement during the COVID-19 pandemic in Chile: challenges and opportunities. European Journal of Teacher Education, 43(4), 587-607. https://doi.org/10.1080/02619768.2020.1820981

*Shahzad, S. K., Hussain, J., Sadaf, N., Sarwat, S., Ghani, U., \& Saleem, R. (2020). Impact of virtual teaching on ESL learners' attitudes under Covid-19 circumstances at post graduate level in Pakistan. English Language Teaching, 13(9), 1-9. https://doi.org/10.5539/elt.v13n9p1

*Spurrier, A., Aldeman, C., O’Neal Schiess, J., \& Rotherham, A. J. (2020). Assessment and accountability in the wake of COVID-19. Bellwether Education Partners. Retrieved November 29, 2020 from http://files.eric.ed.gov/fulltext/ED606417.pdf

Sun, P. C., Tsai, R. J., Finger, G., Chen, Y. Y., \& Yeh, D. (2008). What drives a successful e-Learning? An empirical investigation of the critical factors influencing learner satisfaction. Computers \& Education, 50(4), 1183-1202. https://doi.org/10.1016/j.compedu.2006.11.007

*Svalina, V., \& Ivić, V. (2020). Case study of a student with disabilities in a vocational school during the period of online virtual classes due to Covid-19. World Journal of Education, 10(4), 115-123. https://doi.org/10.5430/wje.v10n4p115

*Syahrin, S., \& Salih, A. A. (2020). An ESL online classroom experience in Oman during Covid-19. Arab World English Journal, 11(3), 42-55. https://dx.doi.org/10.24093/awej/vol11no3.3

*Taguchi, N. (2020). Digitally mediated remote learning of pragmatics. Foreign Language Annals, 53(2), 353358. https://doi.org/10.1111/flan.12455

*The Council of Great City Schools (2020). Assessing language proficiency during extended school closures: Sample questionnaires. Retrieved December $4, \quad 2020 \quad$ from https://www.cgcs.org/cms/lib/DC00001581/Centricity/Domain/35/CGCS_SampleQuestionnaire_K12_v6.pdf

*Tinubu Ali, T., \& Herrera, M. (2020). Distance learning during Covid-19: 7 equity considerations for schools and districts. Southern Education Foundation Issue Brief April 2020. Retrieved November 30, 2020 from http://files.eric.ed.gov/fulltext/ED605744.pdf

*Torun, E. D. (2020). Online distance learning in higher education: E-learning readiness as a predictor of academic achievement. Open Praxis, 12(2), 191-208. https://dx.doi.org/10.5944/openpraxis.12.2.1092

Tricco, A., Lillie, E., Zarin, W., O’Brien, K., Colquhoun, H., Kastner, . . . Straus, S., E. (2016). A scoping review on the conduct and reporting of scoping reviews. BMC Medical Research Methodology, 16(15). https://doi.org/10.1186/s12874-016-0116-4

UNESCO Institute for Statistics (2012). International standard classification of education. ISCED 2011. Retrieved December 7, 2020 from http://uis.unesco.org/sites/default/files/documents/internationalstandard-classification-of-education-isced-2011-en.pdf

*United States Department of Education (2020). Providing services to English learners during the Covid-19 outbreak. Retrieved December 8, 2020, from https://www2.ed.gov/documents/coronavirus/covid-19-elfactsheet.pdf 
*Uro, G., Lal, D., \& Alsace, T. (2020). Uro, G., Lai, D., \& Alsace, T. (2020). Supporting English learners in the COVID-19 crisis. Council of the Great City Schools. Retrieved November 30, 2020 from https://files.eric.ed.gov/fulltext/ED607280.pdf

*Wagner, E. (2020). Duolingo English test, Revised version July 2019. Language Assessment Quarterly, 17(3), 300-315. https://doi.org/10.1080/15434303.2020.1771343

Walsh, S. (2006). Talking the talk of the TESOL classroom. English Language Teaching Journal, 69(4), 133141. https://doi.org/10.1093/elt/cci100

Watson, D. (1993). The Impact Report: An evaluation of the impact of information technology on children's achievements. Kings College.

Whittle, C., Tiwari, S., Yan, S., \& Williams, J. (2020). Emergency remote teaching environment: a conceptual framework for responsive online teaching in crises. Information and Learning Sciences, 121(5/6), 311319. http://dx.doi.org/10.1108/ILS-04-2020-0099

*Yi, Y., \& Jang, J. (2020). Envisioning possibilities amid the COVID-19 pandemic: Implications from English language teaching in South Korea. TESOL Journal, 11(3), 1-5. https://doi.org/10.1002/tesj.543 


\section{APPENDICES}

\section{Appendix 1: Studies included in the analysis}

Internal study ID W: publication taken from WoS; internal study ID E: publication taken from ERIC; see reference list for full bibliographic records.

\begin{tabular}{llll}
\hline Study ID & Publication & Study ID & Publication \\
\hline W4 & Sepulveda-Escobar and Morrison & E1 & Al-Nofaie (2020) \\
W5 & (2020) & & \\
W6 & Gavies et al. (2020) & E2 & Altavilla (2020) \\
W8 & Mideros (2020) & E3 & Education Trust West (2020) \\
W9 & Navarro Cira and Carillo López & E4 & Ero et al. (2020) \\
& E5 & Syahrin and Salih (2020) \\
W10 & Ohara and Ishimura (2020) & & \\
W11 & Schneider (2020) & E8 & Shahzad et al. (2020) \\
W12 & Sayer and Braun (2020) & E9 & Marshall and Kostka (2020) \\
W14 & Yi and Jang (2020) & E12 & United States Department of Education \\
& & & (2020) \\
W15 & Moorhouse and Beaumont (2020) & E12 & Gallardo et al. (2020) \\
W27 & Motteram et al. (2020) & E14 & Svalina and Ivić (2020) \\
W30 & Dubreil (2020) & E17 & Tinubu Ali and Herrera (2020) \\
W36 & Hristakieva (2020) & E18 & Spurrier et al. (2020) \\
W37 & Doncheva et al. (2020) & E19 & Ghounane (2020). \\
W38 & Masterson (2020) & E25 & Research for Action (2020) \\
W40 & Atmojo and Nugroho (2020) & E30 & Inpeng and Nomnian (2020) \\
W47 & Wagner (2020) & E31 & Egbert (2020) \\
W49 & Russell (2020) & E32 & Gacs et al. (2020) \\
W51 & Taguchi (2020) & E33 & Alahmadi and Alraddadi (2020) \\
W52 & Knight (2020) & E39 & Billings and Lagunoff (2020) \\
W53 & Ross and DiSalvo (2020) & & \\
W54 & Lomicka (2020) & & \\
W55 & Guillén et al. (2020) & & \\
W56 & Torun (2020) & & \\
W57 & Kohnke and Moorhouse (2020) & & \\
\hline & & &
\end{tabular}




\section{Appendix 2: Coding categories with operational definitions}

\begin{tabular}{|c|c|c|}
\hline Coding categories & Abbreviation & Operational definition \\
\hline \multicolumn{3}{|l|}{ TEACHERS } \\
\hline Teacher accountability & TACC & $\begin{array}{l}\text { ERT improves teacher accountability in terms } \\
\text { of, for example, creativity, problem solving } \\
\text { skills, autonomy. }\end{array}$ \\
\hline Teacher digital literacy skills & $\begin{array}{l}\text { TDIGLIT+ } \\
\text { TDIGLIT- }\end{array}$ & $\begin{array}{l}\text { ERT helps teachers improve their digital } \\
\text { literacy skills. } \\
\text { ERT constrains teachers due to lack of or } \\
\text { insufficiently developed digital literacy skills }\end{array}$ \\
\hline Monitoring learning & TMON & $\begin{array}{l}\text { Teachers experience problems in assessing } \\
\text { students' learning, monitoring the process, } \\
\text { evaluating their understanding through giving } \\
\text { and receiving feedback. }\end{array}$ \\
\hline Teacher-parents & TPAR & ERT influences teacher-parents relations. \\
\hline Teacher peer support & $\begin{array}{l}\text { TPEER+ } \\
\text { TPEER- }\end{array}$ & $\begin{array}{l}\text { Teachers engage in peer support and/or } \\
\text { experience community to face challenges of } \\
\text { ERT } \\
\text { No or limited teacher peer support/experience } \\
\text { of community to face challenges of ERT }\end{array}$ \\
\hline Inappropriate teaching place & TPLACE & $\begin{array}{l}\text { Conditions of the teachers' environment } \\
\text { impede ERT (excluding technical constraints) }\end{array}$ \\
\hline Planning and material preparation & TPLAN & $\begin{array}{l}\text { Teachers experience challenges when } \\
\text { planning and selecting or developing } \\
\text { materials. }\end{array}$ \\
\hline Psychological effects on teachers & TPSY & ERT exerts psychological effects on teachers. \\
\hline Teacher reflection on teaching & TREFL & $\begin{array}{l}\text { ERT triggers teachers' reflection on } \\
\text { professional issues. }\end{array}$ \\
\hline Teacher restricted access to technology & TTECH & $\begin{array}{l}\text { Teachers cannot benefit from ERT sufficiently } \\
\text { due to limitations related to technical } \\
\text { equipment and/or internet connectivity. }\end{array}$ \\
\hline \multicolumn{3}{|l|}{ STUDENTS } \\
\hline Student appreciation & $\begin{array}{l}\text { SAPPR+ } \\
\text { SAPPR- }\end{array}$ & $\begin{array}{l}\text { Students appreciate instructional practices in } \\
\text { ERT unspecifically. } \\
\text { Students do not appreciate instructional } \\
\text { practices in ERT unspecifically. }\end{array}$ \\
\hline Student digital literacy skills & $\begin{array}{l}\text { SDIGLIT+ } \\
\text { SDIGLIT- }\end{array}$ & $\begin{array}{l}\text { ERT helps students improve their digital } \\
\text { literacy skills. } \\
\text { ERT constrains students due to lack of or } \\
\text { insufficiently developed digital literacy skills. }\end{array}$ \\
\hline Inappropriate study place & SPLACE & $\begin{array}{l}\text { Conditions of the students' environment } \\
\text { impede ERT (excluding technical constraints). }\end{array}$ \\
\hline Psychological effects on students & SPSY & ERT exerts psychological effects on students. \\
\hline Study skills & SSTUDY & $\begin{array}{l}\text { ERT improves study skills in terms of, for } \\
\text { example, students' creativity, self-directed } \\
\text { learning, engagement in activities, problem } \\
\text { solving skills, autonomy }\end{array}$ \\
\hline Intercultural awareness & SCA & $\begin{array}{l}\text { ERT helps students build and/or develop their } \\
\text { intercultural awareness. }\end{array}$ \\
\hline Instructional support & $\begin{array}{l}\text { SSUP+ } \\
\text { SSUP- }\end{array}$ & $\begin{array}{l}\text { Students receive sufficient instructional } \\
\text { support from teachers. } \\
\text { Students receive insufficient instructional } \\
\text { support from teachers. }\end{array}$ \\
\hline Student restricted access to technology & STECH & $\begin{array}{l}\text { Students cannot benefit from ERT sufficiently } \\
\text { due to limitations related to technical } \\
\text { equipment and/or internet connectivity. }\end{array}$ \\
\hline
\end{tabular}




\section{Appendix 2: Coding categories with operational definitions (Continued)}

\begin{tabular}{|l|l|l|}
\hline Coding categories & Abbreviation & Operational definition \\
\hline CLASSROOM PRACTICE & ME+ and ME- & $\begin{array}{l}\text { Effects of the modality of ERT on } \\
\text { instructional practice in online lessons } \\
\text { referring to (but not limited to) interaction, } \\
\text { skills learning, participation in online lessons }\end{array}$ \\
\hline Modality effects: classroom & GS+ & $\begin{array}{l}\text { Schools receive support from the superior } \\
\text { government agency. } \\
\text { Schools receive no or insufficient support } \\
\text { from the superior government agency. }\end{array}$ \\
\hline Governmental support & GS- & $\begin{array}{l}\text { Schools deliver professional support and } \\
\text { development to address challenges of ERT. } \\
\text { Schools deliver no or insufficient professional } \\
\text { support and development to address } \\
\text { challenges of ERT. }\end{array}$ \\
\hline School support for students & SCHT+ & $\begin{array}{l}\text { School precautions help learners address } \\
\text { challenges of ERT. } \\
\text { No or insufficient school precautions help } \\
\text { learners address challenges of ERT. }\end{array}$ \\
\hline
\end{tabular}

$\mathrm{R}=$ The initial " $\mathrm{R}$ " can be applied to all categories in this list meaning "Recommendation". Those codes apply to data coming from articles that intent to provide readers with recommendations or suggestions on how to address the challenges of ERT without focusing on empirical data. 


\section{TÜRKÇE GENIŞLETILMIŞ̧ ÖZET}

Eğitim teknolojilerinin İkinci Dünya Savaşı'ndan sonraki dönemde Amerika Birleşik Devletleri'nde kullanılmasıyla birlikte "film şeritleri, yansıtıcılar, dil laboratuvarları, kasetçalar ve televizyonlar" eğitimdeki yerlerini almaya başlamıştır (Coley vd. 1997, s. 9). Zaman içerisinde yüz yüze eğitim uygulamalarının yanında uzaktan eğitim uygulamaları da ortaya çıkmıştır. Eğitim teknolojilerinin eğitim uygulamalarında yerini almasıyla birlikte "öğretmen, öğrenci, sınıf organizasyonu, kaynaklar, ders/sınıf kültürü ve normlar (kural, rutin ve beklentiler)" gibi kavramlar öğretim senaryosunu etkileyen değişkenler olarak ileri sürülmüștür (Kennewell, 2001, s. 102). Bununla birlikte, Beldarrain'ın (2006) da ifade ettiği gibi, teknoloji sayesinde eş veya farklı zamanlı öğrenme ortamlarında iş birliğinin artırılmasına yönelik ortaya çıkan fursatlara rağmen uzaktan eğitim programlarında birtakım zorluklar ile karışılabilmektedir. Eğitimin herhangi bir hazırlık yapılmaksızın zorunlu bir şekilde uzaktan yürütülmesi ise bu zorlukları arttırmakla birlikte birtakım firsatları da beraberinde getirmektedir. Bu doğrultuda, Covid-19'un neden olduğu salgın tehdidine karş1lık, birçok ülkede çevrimiçi öğretim yoluyla zorunlu uzaktan eğitime geçilmiştir. Yöntemdeki bu değişikliğin hızlı bir biçimde gerçekleştirilmesi gerekmiş ve söz konusu değişiklik, diğer yönlerin yanı sıra, teknolojik altyapı, öğretmenlerin uzaktan öğretim araçlarını kullanma becerisi ve uzmanlığı ile ögrencilerin çevrimiçi öğretimden yararlanmaya hazır olmaları konusunda ihtiyaçlara neden olmuştur. Hedef dilin öğrenme ve öğretme sürecinin hem amacı hem de aracı olması nedeniyle, zorunlu uzaktan eğitimin yabanc1 dil ve ikinci dil öğretimi üzerindeki etkisinin kritik olduğu düşünülmektedir.

Yakın zamanda uygulanmasına rağmen, zorunlu uzaktan eğitimin yabancı ve ikinci dil öğretimi üzerindeki etkileri konusunda giderek artan sayıda araştırma yapılmaktadır. Bu doğrultuda, bu araştırmada, doküman analizi yöntemi benimsenerek 1 Ocak - 28 Ekim 2020 tarihleri arasında yayımlanan çalışmalara yönelik sistematik bir genel bakış geliştirilmesi amaçlanmıştır. İlgili zaman diliminde Web of Knowledge ve ERIC veritabanları üzerinden yayınlanan 97 çalışmaya ulaşılmıştır. Bu çalışmalardan 16 tanesinin her iki veritabanında da tarandığ tespit edilmiştir. Covid-19 salgını ile doğrudan ilgili olduğu düşünülmeyen yabancı dil veya ikinci dil odaklı çalışmalar bu incelemenin dışında bırakılmıştır. Sonuç olarak, toplam 45 adet çalışma kapsam incelemesine dâhil edilmiştir.

İncelemede, araştırma bağlamları (yayın türleri, araştırma yöntemleri, ülkeler, eğitim kademeleri ve katılımcılar), ve öne çıkan bulgular tanımlanmıştır. Bulguların tanımlanmasında bu çalışmanın yazarlarınca ortak yürütülen tümevarımsal içerik analizi yöntemi kullanılmıştır. Buna göre incelenen çalışmaların öne çıkan bulguları kod ve kategoriler ile sınıflandırılmıştır. Kodlama sürecinde ilk olarak 10 çalışma üç yazar tarafından eşzamanlı olarak incelenmiş, sonrasında Zoom üzerinden yapılan toplantılar neticesinde elde edilen kodlar ile bu kodlara ait tanımlamalar belirlenmiştir. 35 çalışma ise yazarların ikili değerlendirmelerine tabi tutulmuş, kodlar üzerinde anlaşmazlık olması halinde söz konusu ikili değerlendirmede yer almayan üçüncü yazarın görüşüne başvurulmuştur. Bu şekilde veri analizinde değerlendiriciler arasında güvenirlik ve geçerlik oluşturulmaya çalışılmıştır. İzlenen bu analiz yöntemi ile, yayımlanan çalışmalardaki eğilimlerin tespit edilmesi ve salgının oldukça yeni olduğu gerçeği göz önüne alınarak zorunlu uzaktan eğitimin yabanc1 veya ikinci dil öğretimi ve öğrenimi üzerindeki etkisine ilişkin ön bulguların raporlaştırılmasına çalışılmıştır. Araştırmanın bulguları, incelenen çalışmaların büyük ölçüde uygulayıcılar, yani okullar, hükümet yetkilileri ve eğitim kurumları ve araştırma çalışmaları tarafından sunulan raporlardan oluştuğunu ve yükseköğretim düzeyinin çalışmalarda en sık ele alınan eğitim bağlamı olduğunu ortaya koymuştur. Bulgular ayrıca, zorunlu uzaktan eğitimin yabanci/ikinci dil öğretmenlerine yönelik kısıtlamalardan çok olanak sağladığını ve hem öğretmenlerin hem de öğrencilerin devlet yetkililerinden, okullardan veya akranlarından yeterli destek almaları ve hâlihazırda edinilmiş dijital becerileri ile mevcut teknik altyapıdan yararlanmaları halinde zorunlu uzaktan eğitimde karşılaşılan zorlukların firsata çevirebileceğini göstermiştir. Söz konusu bulgulara dayanarak, öğretmen, öğrenci ve sınıfla ilgili yönlere odaklanan araştırmaların ikinci/yabancı dillerin zorunlu uzaktan eğitimi sürecinde karşılaşılan zorluklara yönelik çözüm bulunmasına katkı sağlayacağı düşünülmektedir. 
Araştırmada, elde edilen bulgulara dayanarak salgın süresinde zorunlu uzaktan eğitim yoluyla dil öğretimindeki farklı uygulamalar ile alan yazında gelinen noktanın ortaya konmasına çalışılmıştır. Araştırmada ayrıca, zorunlu uzaktan eğitim uygulamalarının beraberinde getirdiği firsat ve güçlüklerin de ele alınmaya, farklı ülke ve eğitim kademelerinde uygulayıcılara yönelik geliştirilen çeşitli önerilere yer verilmeye ve alan yazındaki araştırma boşluğu tanımlanarak ileride yapılacak çalışmalara yön göstermeye çalışılmıştır. Sözgelimi, incelenen çalışmaların birçoğunun Amerika Birleşik Devletleri'nde gerçekleştirildiği ve buna istinaden farklı bağlam ve ülkelerde gerçekleştirilecek araştırma bulgularına gereksinim duyulduğu tespit edilmiştir. Benzer şekilde, incelenen çalışmaların birçoğunun yükseköğretim düzeyindeki uygulayıcıların gözlemlerine dayalı bulgusundan hareketle, daha genellenebilir bulgulara erişilmesi için farklı kademelerden daha fazla paydaşın zorunlu uzaktan eğitim uygulamalarına yönelik görüş ve deneyimlerinin araştırıldığı nitel ve nicel araştırma yöntemlerinin birlikte kullanıldığı karma desenli çalışmalara ihtiyaç olduğu sonucuna varılmıştır. Buna ek olarak, incelenen çalışmalarda zorunlu uzaktan eğitimin öğrenciler açısından zorluk ve firsatları beraberinde getirdiği; öğretmenler içinse zorluktan daha çok firsat sunduğu belirlenmiştir. $\mathrm{Bu}$ çerçevede, öğretmenlerin mesleki gelişimlerini sağlayabileceği üst düzey olanaklar kurumsal düzeyde tanınmalı ve mevcut teknolojik altyapının öğretmen ve öğrencilerin uzaktan eğitim sürecinden etkin bir şekilde istifade etmesine olanak sağlayacak şekilde düzenlenmesi gerekmektedir. Son olarak, öğretmenlerin zorunlu uzaktan eğitim sürecinde kullandıkları platformlar üzerinden sinıf yönetimi ile öğrencilerin derse katılımını sağlama yöntemlerinin araştırılmasına ihtiyaç duyulmakta ve bu alanda elde edilecek verilerin uzaktan eğitim sürecinde öğretmenler ile eğitim politikalarını belirleyenlere 1 şık tutacağına inanılmaktadır. 